NBER WORKING PAPER SERIES

\title{
CURRENCY MISMATCHES, DEBT INTOLERANCE \\ AND ORIGINAL SIN: \\ WHY THEY ARE NOT THE SAME AND WHY IT MATTERS
}

\author{
Barry Eichengreen \\ Ricardo Hausmann \\ Ugo Panizza \\ Working Paper 10036 \\ http://www.nber.org/papers/w10036 \\ NATIONAL BUREAU OF ECONOMIC RESEARCH \\ 1050 Massachusetts Avenue \\ Cambridge, MA 02138 \\ October 2003
}

The views expressed herein are those of the authors and not necessarily those of the National Bureau of Economic Research.

(C2003 by Barry Eichengreen, Ricardo Hausmann, and Ugo Panizza. All rights reserved. Short sections of text, not to exceed two paragraphs, may be quoted without explicit permission provided that full credit, including $(\mathrm{C}$ notice, is given to the source. 
Currency Mismatches, Debt Intolerance and Original Sin: Why They Are Not the Same and Why it Matters

Barry Eichengreen, Ricardo Hausmann, and Ugo Panizza

NBER Working Paper No. 10036

October 2003

JEL No. F0, F33, F34

\begin{abstract}
Recent years have seen the development of a large literature on balance sheet factors in emergingmarket financial crises. In this paper we discuss three concepts widely used in this literature. Two of them - "original sin" and "debt intolerance" - seek to explain the same phenomenon, namely, the volatility of emerging-market economies and the difficulty these countries have in servicing and repaying their debts. The debt-intolerance school traces the problem to institutional weaknesses of emerging-market economies that lead to weak and unreliable policies, while the original-sin school traces the problem instead to the structure of global portfolios and international financial markets. The literature on currency mismatches, in contrast, is concerned with the consequences of these problems and with how they are managed by the macroeconomic and financial authorities. Thus, the hypotheses and problems to which these three terms refer are analytically distinct. The tendency to use them synonymously has been an unnecessary source of confusion.
\end{abstract}

\author{
Barry Eichengreen \\ Department of Economics \\ University of California \\ Berkeley, CA 94720 \\ and NBER \\ eichengr@econ.berkeley.edu \\ Ricardo Hausmann \\ Kennedy School of Government \\ Harvard University \\ Cambridge, MA 02138 \\ ricardo_hausmann@harvard.edu
}

Ugo Panizza

Interamerican Development Bank

1300 New York Avenue, NW

Washington, DC 20009

ugop@iadb.org 


\section{Currency Mismatches, Debt Intolerance and Original Sin: Why They are Not the Same and Why it Matters \\ Barry Eichengreen, Ricardo Hausmann and Ugo Panizza September 2003}

\section{Introduction}

Recent years have seen the development of a large literature on balance-sheet factors in financial crises. ${ }^{1}$ The balance-sheet approach focuses on the impact of disturbances on the assets, liabilities and net worth of households, firms, government, and the economy as a whole and on the implications for growth and stability. Some studies focus on the net worth effects of shocks to the exchange rate in the presence of foreign currency denominated liabilities. Others look at liquidity or interest rate shocks when the tenor of a bank, firm or country's liabilities is shorter than the tenor of its assets. In some studies the propagation mechanism is the impact on consumption and investment of the change in net worth of households and nonfinancial firms. In others it is the impact on the liquidity and solvency of financial institutions and markets and hence on confidence in the financial system. In still others it is the impact on the sustainability of the public debt.

Recent contributions also differ in their assumptions about the distortion giving rise to these fragilities. Our own work focuses on problems with the structure of global financial markets that result in the inability of economies to borrow abroad in their own currencies. ${ }^{2}$ Others focus on policy failures as a result of which governments fail to limit

\footnotetext{
${ }^{1}$ See for example Krugman (1999), Razin and Sadka (1999), Aghion, Bacchetta, and Banerjee (2000), Céspedes, Chang and Velasco (2002), and Jeanne (2002).

${ }^{2}$ See Eichengreen and Hausmann (1999) and Eichengreen, Hausmann and Panizza (2003a).
} 
foreign-currency and short-maturity borrowing to socially desirable levels and/or fail to insure adequately against its potentially destabilizing consequences. ${ }^{3}$

Hence, while all of these studies are concerned in a broad sense with openeconomy balance-sheet effects, the issues on which they focus are not the same. These different emphases lead to different perspectives on research and policy.

In Section 2 we introduce several concepts that are widely used in the literature, describe how they differ, and explain why these differences matter. We distinguish "currency mismatches" (differences in the currencies in which assets and liabilities are denominated); "debt intolerance" (the inability of emerging markets to manage levels of debt that are manageable for advanced industrial countries); and "original sin" (the difficulty emerging markets face when attempting to borrow abroad in their own currencies). We emphasize that the phenomena denoted by these terms are analytically distinct.

In Section 3 we show that these distinctions matter empirically as well as conceptually. We analyze the impact of balance-sheet variables on the volatility of output, the volatility of capital flows, the management of exchange rates, and credit worthiness of countries. We show that it is important when considering the behavior of such variables to clearly distinguish original sin, debt intolerance, and currency mismatches. Section 4 addresses a number of additional debates that have arisen in this context, after which Section 5 summarizes our conclusions.

\footnotetext{
${ }^{3}$ See for example Goldstein and Turner (2003) and Reinhart, Rogoff and Savastano (2003).
} 


\section{Currency Mismatch, Debt Intolerance and Original Sin are not the Same}

Three terms that are prevalent in this literature - currency mismatches, debt intolerance and original $\sin$ - in fact refer to quite different phenomena.

Original Sin. Eichengreen, Hausmann and Panizza (2003a) define original sin as the inability of a country to borrow abroad in its own currency. ${ }^{4}$ This focus on external borrowing is motivated by the observation that, in the absence of other distortions, world welfare would be enhanced if capital flowed from capital-rich advanced countries to their more capital-poor emerging market counterparts. It would be further enhanced if countries could use the current account and the capital flows needed to finance it to stabilize the domestic economy when faced with shocks. ${ }^{5}$

One possible explanation for the failure of more capital to flow from rich to poor countries and the difficulty experienced by the latter in using the capital account to smooth consumption is their inability to borrow abroad in their own currencies. If a country's external debt is denominated in foreign currency, then real exchange rate depreciation, by reducing the purchasing power of domestic output over foreign claims, will make it more difficult to service that debt. Knowing that shocks affecting the real

\footnotetext{
${ }^{4}$ In earlier work, Eichengreen and Hausmann (1999) used the term to refer to both the difficulty that countries experience when attempting to borrow abroad in their own currencies and the difficulty they face when attempting to borrow at home at long maturities. In subsequent work we came to conclude that the first of these two problems is particularly difficult. While it is not easy to develop domestic bond markets something that is the sine qua non of facilitating the efforts of firms and government to borrow at home at long maturities - a growing number of countries are showing an ability to do so. Chile, Hungary, India and Thailand, among other countries, are able to borrow on domestic markets at fixed rates without indexing their bonds to the exchange rate, as documented in Section 4 below. But these same countries are making less progress in developing the ability to borrow abroad in their own currencies. In Eichengreen, Hausmann and Panizza (2003a) we have also devoted some attention to "the domestic aspect" of original sin. But because the constraints on borrowing abroad in one's own currency seem particularly intractable, we have made this the focus of our recent work and adopted a correspondingly narrower definition of original sin. We return to these issues in Section 4 below.

${ }^{5}$ That net capital flows from relatively capital-rich to relative-capital poor countries are not larger is referred to as the Lucas Paradox (after Lucas 1990). That capital flows are pro-cyclical, exacerbating booms and recessions, has also been widely commented upon (see for example Gavin, Hausmann and Leiderman 1995).
} 
exchange rate can disrupt the country's ability to service its debt, foreigners may be rendered less willing to lend. And since the real exchange rate tends to strengthen in good times and weaken in bad times, foreign-currency debt will be harder to service in bad times, reducing willingness to lend and thereby accentuating the pro-cyclical nature of capital flows.

Aware of these dangers, a government may use macroeconomic and regulatory policies to limit foreign borrowing. But then capital still will not flow from capital-rich to capital-poor countries, nor will countries be able to cushion the effect of shocks through international borrowing. The government may accumulate foreign reserves to be used to intervene in the foreign exchange market in order to prevent the currency from moving and/or to enable it to act as debt servicer of last resort. But in this case, the country's gross foreign currency liabilities, accumulated by borrowing abroad, are matched by gross foreign currency assets which the government holds in the form of international reserves. If reserves equal gross foreign borrowing, then there will again be no capital transfer from capital-rich to capital-poor economies.

In part, debate on these questions revolves around the realism of the premise that other distortions are absent or at least that they are not the main thing going on. A contrary view is that the inability of emerging markets to borrow abroad in their own currencies is simply a corollary of other distortions to their economies that remove the incentive for lending and borrowing. Weak policies and institutions in emerging markets so depress the marginal productivity of capital, in this view, that neither the welfare of these countries, nor that of the world as a whole, is enhanced by capital transfer. 
Foreigners are not inclined to invest in emerging markets, in this view, because

productivity there is so low.

The intermediate position is that domestic policies and institutions are important for the ability of countries to borrow abroad in their own currencies but so are factors largely beyond the control of the individual country. ${ }^{6}$ Foreign investors may be reluctant to lend to a country in its own currency if the authorities are prone to manipulating the value of that currency. Institutional and policy reforms giving investors confidence that the value of the currency will be maintained may thus be necessary for a country to be able to borrow abroad in its own currency. But the evidence does not suggest that they are sufficient; too many countries with strong policies and institutions also suffer from original sin. Moreover, if the problem was fear of inflation, we should observe inflationindexed local-currency debts or contracts in the currencies of a variety of well-behaved countries. Instead, we observe a large concentration of debt denominated in a few major currencies. $^{7}$

Chile is a favorite example of a country with increasingly strong institutions and policies. In terms of rule of law, the International Country Risk Guide (ICRG) gave Chile 5 of 6 possible points in 2001, compared to a Latin American average of 2.9 and a world average of 3.8. Chile has also done a good job at managing the risks associated

\footnotetext{
${ }^{6}$ This is a fair summary of our view.

${ }^{7}$ Of the nearly $\$ 5.8$ trillion in outstanding securities placed in international markets in the period 19992001, $\$ 5.6$ trillion was issued in 5 major currencies: the US dollar, the euro, the yen, the pound sterling and Swiss franc. See Eichengreen, Hausmann and Panizza (2003a). To be sure, the residents of the countries issuing these currencies (in the case of Euroland, of the group of countries) constitute a significant portion of the world economy and hence form a significant part of global debt issuance. But while residents of these countries issued $\$ 4.5$ trillion dollars of debt over this period, the remaining $\$ 1.1$ trillion of debt denominated in their currencies was issued by residents of other countries and by international organizations (which issued a total of $\$ 1.3$ trillion of debt). The causes and consequences of this concentration of debt denomination in few currencies are the focus of the literature on original sin.
} 
with foreign borrowing, using capital account regulation, prudential supervision, transparency requirements for banks and firms, and flexible exchange rates to encourage prudent management of foreign currency exposures. ${ }^{8}$

One thing that these strengthened policies and institutions have not done, however, is to enable Chile to borrow abroad in its own currency. The consequences have been significant. In 1998 Chile was hit by an adverse terms-of-trade shock. A country able to borrow abroad in its own currency, when hit by this temporary shock, would have eased monetary and fiscal policies, loosened the exchange rate, and financed its growing external deficit by borrowing abroad in order to smooth consumption and stabilize production. This is what Australia did, for example, when hit by the same global shock. ${ }^{9}$ But Chile, rather than seeing capital inflows buffer its export shock, suffered a sudden stop in such flows, forcing it to cut its imports by fully 22 percent (nearly 6 per cent of GDP) between 1997 and 1999. This entailed a collapse in GDP growth from 6.8 percent in 1997 to -0.8 percent in $1999 .{ }^{10}$ These are large swings by the standards of the advanced-industrial economies.

Why did Chile's performance resemble that of Latin American countries plagued by weak institutions rather than that of advanced countries with comparable institutionalquality ratings like Australia? Original sin may be part of the answer. If Chile pursued accommodative policies and allowed the real exchange rate to adjust, adverse balance sheet effects would have created doubts about its ability to service its debt, limiting the

\footnotetext{
${ }^{8}$ These policies are a reasonable approximation of the emerging consensus on how a prudent emerging market should manage the risks of external borrowing.

${ }^{9}$ This is the counterexample considered in Eichengreen and Hausmann (1999). This comparison is pursued by Caballero, Cowen and Kearns (2003), whose interpretation differs.

${ }^{10}$ Calculations based on data for imports and GDP from the Central Bank of Chile. For a discussion of the costs of sudden stop in capital flows see Calvo, Izquierdo and Talvi (2002).
} 
willingness of the foreign investors to fund the ensuing deficit. By opting for restrictive policies, the authorities curtailed the demand for foreign finance so as to limit the increase in country risk, but at the cost of a major recession. ${ }^{11}$

The Chilean authorities were not aware of these dangers, but the ex ante policies available to limit the country's vulnerability to sudden stops had costs as well. Gallego and Hernandez (2003) show that the non-interest-bearing deposit requirement imposed on foreign borrowing in the 1990s increased the cost of external finance for Chilean firms. This does not mean that these policies were inadvisable; we have argued elsewhere that such costs were worth paying. ${ }^{12}$ In effect they were optimal second-best policies - they were a sensible way of insuring against the risk of sudden stops given that external debt was denominated in foreign currency. But the distance to the first best was substantial because the policies in question entailed a tradeoff between access to external finance on the one hand and financial stability on the other. Chile was able to attain a reasonable position on this frontier owing to the strength of its policies and institutions. Even better, of course, would have been to have been able to push that frontier outward by acquiring the ability to borrow abroad in local currency.

It is striking in this context that Chile, despite the strength of its institutions, has been unable to escape the problem of original sin that was a constraint on shifting that frontier. This is a specific example of the general point that the standard institutionstrengthening measures appear to have relatively little ability over policy-relevant horizons to enable developing countries to acquire the capacity to borrow abroad in their

\footnotetext{
${ }^{11}$ After 2000 and especially after 2002, policies became more accommodative and the real exchange rate was allowed to depreciate by 38.6 percent from its peak in 1997. However, capital inflows have yet to resume and growth has remained lackluster, as would be expected given the less expansionary effect of depreciations in countries that suffer from original sin.

${ }^{12}$ See Hausmann and Gavin (1996) and Eichengreen (2002).
} 
own currencies. ${ }^{13}$ The label "original sin" is designed to convey the possibility that the problem may not result only from the actions of the affected country but in addition may have something to do with factors largely beyond its immediate determination and control. ${ }^{14}$

Debt Intolerance. Reinhart, Rogoff and Savastano (2003) define debt intolerance as the inability of emerging markets to manage levels of external debt that are manageable for advanced countries. They operationalize the concept as the relationship between a country's credit rating (also referred to as country risk) and its external debt. They report that ratings fall more rapidly with debt in emerging markets than advanced countries, as if the former have less debt management capacity.

Debt intolerance and original sin are not the same. The inability of a country to borrow abroad in its own currency is one potential explanation for why it may have trouble managing levels of debt that would be manageable for other countries. But no one to our knowledge has claimed that original sin is the only determinant of debt problems. $^{15}$

Reinhart, Rogoff and Savastano write that “a country's external debt intolerance can be explained by a very small number of variables related to its repayment history." They show that countries that defaulted in the past and have histories of inflation have

\footnotetext{
${ }^{13}$ See Section 3 for additional evidence.

${ }^{14}$ We will have more to say about the specific nature of these factors below.

${ }^{15}$ This point would not be worth making except that some contributors to the literature have referred interchangeably to countries' external debt problems in general (its "country risk" or "debt intolerance") and their inability to borrow abroad in their own currencies in particular ("original sin"). See Reinhart, Rogoff and Savastano (2003), p.22. In our previous work and again below, we analyze the determinants of a country's debt problems, as measured by their credit ratings. This is the approach also taken by Reinhart, Rogoff and Savastano. We study the impact of original sin on credit ratings controlling for several other potential determinants of ratings such as a country's per capita income and its overall indebtedness. This makes clear that we do not see original sin as the only determinant of country risk, although we do find that it is an important determinant.
} 
lower credit ratings in the present. We endorse the insight that history can play an important role in shaping current outcomes. But a minimal condition for a theory of the historical determinants of current events is a transmission mechanism through which events in the past can influence outcomes in the present. ${ }^{16}$ One would also want evidence that this mechanism is at work, for otherwise one could not rule out that omitted factors associated with external debt servicing difficulties in both the past and present explain the observed correlation, where in fact there is no causal mechanism linking past events to current outcomes.

The authors conjecture that default on external debt may weaken a country's financial system and that a weaker financial system increases the likelihood of subsequent default because countries with weaker financial systems suffer larger output losses when access to external finance is interrupted. They suggest that default on external debt may weaken a country's tax system by encouraging capital flight and tax avoidance, in turn making it harder to raise the revenues needed to service public debts. But they report no regressions relating the size of the financial system and the tax base to countries' histories of default, and no regressions relating current default to the size of the financial system and the tax base. They present no evidence of these or other mechanisms causally linking past defaults to current debt servicing difficulties. ${ }^{17}$

That the same countries have defaulted in both the distant and more recent past may in fact reflect other characteristics of those countries that are slow to change but which are omitted from this analysis of debt intolerance. Original sin may be one such characteristic. Elsewhere we have shown that the inability of countries to borrow abroad

\footnotetext{
16 There is now a large literature on this subject. See the discussion in David (2001).

${ }^{17}$ In principle, empirical work along these lines should be feasible. We return to this in the concluding section of our paper.
} 
in their own currencies is persistent. ${ }^{18}$ Similarly, that the commodity composition of exports renders some countries' terms of trade persistently more volatile than others may explain why some countries have more difficulty than others in coping with external debt. $^{19}$

Reinhart, Rogoff and Savastano regress credit ratings as a measure of debt servicing prospects on the history of debt and inflation, using data for 53 advanced and developing countries. To determine whether developing countries are less able to manage debts that are manageable for advanced economies, they enter debt/GNP separately for countries with high credit ratings (67.7 and above on the Institutional Investor hundred-point scale) and low credit ratings (below 67.7). ${ }^{20}$ In support of their hypothesis, they point to the fact that the coefficient on the debt/GNP ratio is negative for countries with low ratings and positive for countries with high ratings and to the high $\mathrm{R}^{2}$ of the regression.

We see three problems with this analysis. First is the omitted variables problem described above. ${ }^{21}$ Second credit ratings appear on both sides of this equation, as a continuous variable on the left and a dummy for above or below 67.7 on the right (interacted with the debt ratio). This makes it hard to draw much comfort from the high $\mathrm{R}^{2}$. Third, there is no separate intercept for countries with credit ratings below 67.7. Hence all respects in which countries with low credit ratings differ from countries with

\footnotetext{
${ }^{18}$ Eichengreen, Hausmann and Panizza (2003b) use the measures of original sin circa 1850 constructed by Flandreau and Sussman (2003) to document the correlation between original sin then and now.

${ }^{19}$ Blattman, Hwang and Williamson (2003) suggest that the commodity composition of exports and resulting behavior of the real exchange rate have persistent implications for volatility and growth.

${ }^{20}$ Some of their regressions also include the percentage of sample years in which the debt was in default or restructuring.

${ }^{21}$ To put the same point another way, the authors put a structural interpretation on an extremely reducedform relationship.
} 
high credit ratings are loaded into the interaction term between credit ratings and the debt/GNP ratio.

In Table 1 we show the difference that this makes. The first regression relates credit ratings to debt/GDP separately for advanced and developing countries but does not include a separate intercept for the latter. Here we use Standard \& Poor's rating data instead of those from Institutional Investor in order to preserve comparability with our previous work and further results reported below. ${ }^{22}$ Despite using slightly different country samples and data, we obtain the same result as Reinhart, Rogoff and Savastano, namely that the coefficient on the debt ratio is significantly larger for developing countries. ${ }^{23}$ The second regression then shows that this result evaporates when a separate intercept is included.

In equation 3 , we split the sample not into advanced and developing countries but into countries with high and low credit ratings, following Reinhart, Rogoff and Savastano. We generate a dummy variable that takes value one if a given country has a

\footnotetext{
${ }^{22}$ Our rating variables is from Standard and Poor's and ranges between 0 and 19. (We converted the S\&P rating into a numerical variable by adopting the following criterion: selective default $=0, \mathrm{C}=2, \mathrm{CC}=2.5$, $\mathrm{CCC}=3, \mathrm{~B}-=4$, and each extra upgrade $=$ one point. A value of 19 corresponds to AAA.) We also adjust our classification for the outlook assigned by S\&P to each country and increase the rating by 0.33 when the country has a positive outlook and decrease the rating by 0.33 when the country has a negative outlook. The rating variable used by Reinhart, Rogoff and Savastano is from Institutional Investor and ranges from 0 to 100 . We report regressions using this alternative measure below.

${ }^{23}$ There are two additional differences between these regressions and the ones in Reinhart, Rogoff and Savastano (RRS). First, since our rating variable is censored at 19 (and more than ten percent of observations are at the upper bound) we use a Tobit model instead of OLS. The results are robust to estimating these equations by OLS instead of Tobit. Second, we use averages over the 1993-99 period, while RRS use averages for the 1979-2002 period. Finally, while the two samples have similar size (62 countries in our sample, 53 in RRS), they do not overlap perfectly. We do not know exactly which countries are included in RRS's regressions. However, in appendix B1 of their paper, they list 63 countries for which they have information on credit rating. Presumably, the 53 countries included in the regressions are a sub-set of this sample. There are 23 countries included in our sample but not in table B1 of Reinhart, Rogoff and Savastano and 24 countries included in table B1 of RRS but not in our sample (these countries are listed in the appendix).
} 
rating above the mean plus one standard deviation of our cross-country sample. ${ }^{24}$

Column 3 reproduces their result: the coefficients on the debt ratios for high and low rated countries are significantly different from one another at standard confidence levels. ${ }^{25}$ But when in column 4 we allow the two groups of countries to have a different intercept, the point estimate and the statistical significance of the difference in slope coefficients again collapses.

In the last three columns of the table we replace the Standard and Poor's rating variable used in the first four columns with the Institutional Investor rating (which varies from 0 to 100) used by Reinhart, Rogoff and Savastano. When we intersect the Institutional Investor rating with the sample of countries for which we have information on debt relative to GDP we are left with a sample of 45 countries. We separate the sample into countries with high and low credit ratings using the same threshold used by Reinhart, Rogoff and Savastano (67.7). Column 5 reproduces their result: the effect of debt/GDP is positive and significant in countries with high credit ratings and negative and significant in countries with low credit ratings. The difference between the two groups is also statistically significant. In column 6, we allow the two groups of countries to have different intercepts and find that the coefficients of debt over GDP are no longer significant in either group of countries. ${ }^{26}$ Furthermore, the difference between the two coefficients is no longer significant at conventional confidence levels. The results are also sensitive to the inclusion of an outlier, South Korea, which has relatively low levels

\footnotetext{
${ }^{24}$ Reinhart, Rogoff and Savastano also separate their sample at the mean plus one standard deviation. On our numerical scale, this corresponds to a cutoff of 16.

${ }^{25}$ That the results are very similar to the preceding set of regressions is not surprisingly. Only two countries that we classify as advanced have low ratings (Greece and Iceland), while just one country that we classify as has developing has a high rating (Singapore).

${ }^{26}$ The point estimates are also very different from those in the regressions omitting the additional intercept term.
} 
of debt and a high credit rating. If Korea is dropped (column 7), the difference between the coefficients of high and low rating countries declines still further. ${ }^{27}$

Currency Mismatch. Original sin also differs from currency mismatches, defined as differences in the values of the foreign currency denominated assets and liabilities on the balance sheets of households, firms, the government and the economy as a whole. In the case of a bank, the concept of a currency mismatch is familiar: it is the difference between the value of the foreign currency denominated liabilities and assets (typically normalized by total assets, total domestic-currency assets, or another appropriate scale variable). For a firm, the currency mismatch derives from the relationship between net foreign-currency denominated liabilities and the net present value of domestic-currency denominated cash flow. A firm with a currency mismatch will experience an adverse balance-sheet effect if exchange-rate depreciation raises the value of its net foreign-currency denominated liabilities relative to the net present value of its cash flow. ${ }^{28}$

When we aggregate this up to the national level, consolidating the foreign currency assets and liabilities of residents, we are left with the aggregate currency mismatch. This means that there will be an aggregate currency mismatch when there is a net debt to foreigners denominated in foreign currency. The implications for the country then parallel those for the firm: real exchange rate depreciation that raises the value of a

\footnotetext{
${ }^{27}$ If panel data methods are used instead of simple cross-country comparisons, the difference between the coefficients of high rating and low rating countries remains statistically significant also after controlling for country fixed effects. Fixed effect estimates may however be problematic (they amplify the noise to signal ratio) in a setting where the fixed effects explain 90 percent of the variance of the dependent variable and 80 percent of the variance of the explanatory variable.

${ }^{28}$ If depreciation is fully translated into higher prices for firms' output, as would happen with a small exporting firm or when there is a full passthrough of exchange rates into prices, there will be no change in the net worth of a company. But this is not the general case.
} 
country's external net debt in terms of the value of its national output will create adverse balance-sheet effects.

However, the aggregate mismatch that exists when there is a net debt to foreigners denominated in foreign currency is different from original sin, defined as the inability of a country to borrow abroad in its own currency and measured as the ratio of foreigncurrency denominated gross debt to foreigners as a share of total gross debt to foreigners. By definition, when banks, firms or public agencies of a country suffering from original sin borrow abroad, they incur a gross foreign debt denominated in foreign currency. But the country may or may not also incur a currency mismatch, depending on how the authorities respond to that act of borrowing. One consequence of original sin is the tendency for countries afflicted by this problem to accumulate international reserves as a way of protecting themselves from potentially destabilizing financial consequences. We show in Section 3 that countries with high levels of original sin do in fact hold significantly larger international reserves, other things equal.

But where reserve accumulation is large, currency mismatches will be small. Thus, where an aggregate mismatch is one possible consequence of original sin, it is not a necessary one. While one possible consequence of original sin is a currency mismatch, another possible consequence is a large reserve accumulation. Either or to some extent both may occur.

Currency mismatches may have costs. But large reserve holdings may also have costs, since the yield on reserves is typically less than the cost of funds. If governments settle on an interior solution to their optimization problem, they are likely to accumulate reserves that offset some fraction less than one of gross foreign debt denominated in 
foreign currency. The resulting currency mismatch will be smaller than the gross debt denominated in foreign currency, while reserve holdings will be larger than in a country that can borrow in domestic currency terms.

It thus makes no sense to criticize measures of original sin as poor measures of aggregate currency mismatches. Authors concerned with the two concepts are attempting to measure different things.

Currency mismatches may have other causes besides original sin. If banks are undercapitalized, risk management is weak, and prudential supervision is inadequate, moral hazard may tempt banks to fund themselves in foreign currency at low interest rates and on-lend in domestic currency at high rates, ignoring the fact that they incur a currency mismatch that leaves them vulnerable to exchange rate fluctuations. ${ }^{29}$ Or a government may neglect the need to accumulate reserves as insurance against exchange rate shocks when foreign debt is denominated in foreign currency terms. Or the authorities may mislead banks and firms into believing that the exchange rate will remain pegged forever, encouraging them to underestimate exchange risk and hence the danger of open positions in foreign currency. Original sin may result in mismatches, depending on how the authorities manage its consequences. But we have never suggested that only original sin matters for currency mismatches, as asserted in some discussions of our work. Nor have we asserted that the strength of a country's institutions and policies is irrelevant for managing the consequences of original sin.

In particular, countries with strong institutions, capable of running strong policies, are in the best position to cope with the potential mismatch problem. They can accumulate reserves. They can limit foreign borrowing. They can operate more flexible

\footnotetext{
${ }^{29}$ This is an element of Goldstein's (1998) analysis of the Asian crisis.
} 
exchange rates. All of these steps may help to limit currency mismatches and financial fragility. ${ }^{30}$ But these measures are second best. The first best would involve having the capacity to borrow from foreigners without incurring a currency mismatch.

This is just another way of saying that the measures that countries use to insure against mismatches are not without cost. Limiting access to foreign borrowing may limit investment. Reserve accumulation is costly. Flexible exchange rates are more problematic in countries with large shares of foreign currency denominated debt. Thus, measures to limit the consequences of original sin taken by countries with the institutional capacity to implement them may come at a cost, as discussed above. This is the sense in which such measures may be incompletely successful at reconciling growth and stability.

\section{How these Differences Matter in Practice}

We now show that these distinctions matter in practice. We start by constructing measures of original sin and presenting evidence of its consequences for policy, the volatility of growth and capital flows, and country credit worthiness. ${ }^{31}$ We then repeat the exercise adding measures of aggregate currency mismatches and debt intolerance. The results suggest that the effects of original sin are the more statistically robust than those of these alternative concepts.

Original Sin. Our index of original sin is. ${ }^{32}$

\footnotetext{
${ }^{30}$ Thus, where previous authors have said that in empirical work like that presented below we minimize the importance of macroeconomic and prudential policies for currency mismatches, they are confusing currency mismatches with original sin.

${ }^{31}$ This material is drawn from Eichengreen, Hausmann, and Panizza (2003a).

${ }^{32}$ In Eichengreen, Hausmann and Panizza. (2003a), we develop some additional measures of original sin and discuss their strengths and weaknesses.
} 


$$
\operatorname{OSIN}_{i}=\max \left(1-\frac{\text { Securities in currency } i}{\text { Securities issued by country } i}, 0\right)
$$

The numerator includes all securities issued in currency $i$ regardless of the nationality of the issuer. We adopt this formulation because if residents of countries different from $i$ issue bonds in currency $i$, these bonds can then be used by residents of country $i$ to swap their foreign currency obligations into domestic currency obligations. This opportunity to hedge would not be captured by an index that only includes local currency debt issued by residents. Although $\frac{\text { Securities in currency } i}{\text { Securities issued by country } i}$ can be greater than one (for countries which issue currencies that are widely used by nonresidents), we bound $O S I N$ at zero because countries cannot hedge more debt than they have.

This index includes bonded international debt but does not include cross-border bank loans, since the Bank for International Settlements does not provide detailed currency breakdowns of international loans. ${ }^{33}$ We therefore weight each observation in the regression analysis below by the share of securities in total foreign debt. ${ }^{34}$

Table 2 presents simple averages of OSIN for several groups of countries. The financial centers (United States, United Kingdom, Switzerland and Japan) have the lowest levels of original sin (in an obvious sense since this is what defines them as financial centers). They are followed by the Euroland countries. Evidently, the advent of the euro (whose introduction provides the dividing point between the two periods in the

\footnotetext{
${ }^{33}$ In Eichengreen, Hausmann and Panizza (2003a) we construct an alternative measure that takes into account bank loans. However, in order to construct this index it is necessary to make assumptions about the currency composition of these loans.

${ }^{34}$ The weight is equal to (total securities issued by country $i$ )/(total bank loans + total securities issued by country $i$ )
} 
table) led to a drop in original sin in Euroland countries. ${ }^{35}$ Developing countries have comparatively high levels of original sin, with Latin America having the most and Eastern Europe the least.

As argued above, we expect countries with original sin to be more inclined to accumulate international reserves and to use them to stabilize the exchange rate. Table 3 tests these hypotheses. All regressions in this table control for the level of development, (proxied by the log of GDP per capita), openness, and foreign debt (total debt securities plus international loans) as a share of GDP. All variables are averages for the period $1993-1998 .^{36}$

Column 1 considers the choice of exchange rate regime. The dependent variable LYS is the de facto classification of Levy-Yeyati and Sturzenegger (2000), which equals 1 for countries with floating exchange rates, 2 for countries with intermediate regimes, and 3 for countries with fixed rates. Since this measure increases with exchange rate inflexibility, we expect a positive relationship with original sin. The coefficient in question is positive and significant, indicating that countries with original sin float less freely. ${ }^{37}$ The coefficient is also economically important. It suggests that moving OSIN from 1 to 0 is associated with a jump of one and a half points on the Levy-Yeyati and Sturzenegger (2000) three-point scale. Countries previously inclined to peg will move to limited flexibility, while countries previously following policies of limited flexibility will

\footnotetext{
${ }^{35}$ This is to be expected, since all of them, including a number of small ones which had not previously enjoyed the privilege, immediately became issuers of a major currency.

${ }^{36}$ Since Table 2 suggests a structural shift in 1999.

${ }^{37}$ Since $L Y S$ is bounded at 1 and 3, we estimate the equation using double-censored Tobit. In Eichengreen, Hausmann and Panizza (2003a) we explore whether this result could be due to reverse causality. We refer the reader to that paper for further discussion.
} 
be inclined to float. Original sin is one explanation, then, for the fear-of-floating phenomenon.

Next we explore whether countries with high levels of original sin hold more reserves. As noted in Section 2, this relationship sheds light on the connections between original sin and currency mismatches. Since reserves are often used to intervene in the exchange rate market, their level may also shed light on the freedom of the float. The dependent variable here is international reserves normalized by M2 (denoted RESM2). Column 2 shows that the coefficient on OSIN is positive, as expected, and significant, as before. The estimated coefficient implies that the increase in reserves in a country where OSIN equals 1 instead of 0 is 25 percent of M2.

Following Bayoumi and Eichengreen (1998a,b) we also define the freedom of the float as the volatility of exchange rates relative to the volatility of reserves (we denote the ratio as $R V E R$ ). If countries with original sin are less inclined to float, we would expect a negative coefficient. Column 3 supports this hypothesis.

Next we consider the relationship between original sin and volatility of growth and capital flows. ${ }^{38}$ There are at least three reasons why original sin may be positively correlated with volatility. First, it limits the authorities' capacity to undertake countercyclical policies. Second, dollar liabilities limit the central bank's ability to act as a lender of last resort. Third, dollar-denominated debt increases the costs of currency depreciations that, in the event of a currency crisis, may lead to large falls in output.

Table 4 confirms the existence of a positive and statistically significant relationship between original sin and macroeconomic volatility. The estimated

\footnotetext{
${ }^{38}$ Besides the independent variables included in Table 3, we also control for the volatility of terms of trade. All equations are estimated by weighed OLS using robust standard errors.
} 
coefficient implies that going from OSIN of 0 to an OSIN of 1 raises the volatility of GDP growth by 1.1 percentage points. Given that the average volatility of GDP growth is 1.5 percent in industrial countries and 3.5 percent in developing countries, original sin may account for a significant part of the difference.

A final set of equations further explores the relationship between original sin and credit ratings (introduced in Table 1 above). We expect original sin to be negatively related to ratings because it makes the cost of servicing debt dependent on a real exchange rate that is pro-cyclical, increasing the states of the world in which payment is difficult. ${ }^{39}$ We regress credit ratings on OSIN, several standard fiscal indicators (public debt over GDP, public debt over government revenues), the country's level of economic development (as proxied by per capita income), and the share of external debt in GDP. Standard \& Poor's rating data, adjusted as above, are used in what follows.

We find a strong and negative correlation between original sin and credit ratings. Columns 1-5 of Table 5 confirm that original sin is correlated with creditworthiness even after controlling for the level of development, total external debt, public debt relative to GDP or revenues, terms of trade volatility, and the real exchange rate volatility. ${ }^{40}$ A drop in OSIN from 1 to 0 is associated with a five-notch improvement in credit ratings. This would push most countries in the sample above investment grade.

Currency mismatches. Goldstein and Turner (2003) suggest that original sin has been improperly used as a proxy for aggregate currency mismatches. To this we would

\footnotetext{
${ }^{39}$ Hausmann (2003) provides a value-at-risk model of credit ratings and shows that original sin makes debt service depend differently on the variances and covariances of output, the real exchange rate and the real interest rate. Moreover, the arguments already presented explain why these variances and covariances are themselves different in countries with original sin.

${ }^{40}$ The volatility of the real exchange rate may be persistent (depending on openness of the economy and the commodity composition of exports), and it is likely to be correlated with the probability of payment difficulties.
} 
only say "not by us." They suggest that a measure of aggregate mismatches should take into account the currency composition of domestic debt. This is incorrect, since if that debt is domestically held, the assets and liabilities of residents cancel out in the aggregate. To the extent that domestically-issued, foreign-currency denominated or linked debt is held by foreigners, that is another issue. Such debt falls conceptually under the heading of foreign currency denominated external debt.

In practice, holdings of domestically-issued, foreign-currency debt owned by foreigners are not easy to track. Some information can be obtained by a report on the currency composition of all holdings by U.S. residents of foreign securities for 2001 issued by U.S. Department of Treasury. This report has the advantage that it includes holdings of locally-issued instruments; its disadvantage is that it covers only the holdings of U.S. residents. These data, summarized in Table 6, corroborate the idea that the global portfolio is concentrated in very few currencies and that, by implication, the issuers of other currencies suffer from original sin (in other words, that the claims they sell to foreigners are predominated denominated in foreign currencies, whether these are issued on foreign markets or not). Of the $\$ 648$ billion of financial claims on foreigners held by U.S. residents in 2001, $\$ 456$ billion (fully 70 percent) were denominated in U.S. dollars. U.S. residents hold 50.9 percent of their claims on Euroland countries in euros and 22.5 percent of their claims on other advanced countries in the currencies of those countries but only 3.1 percent of their claims on developing countries in the currencies of those developing countries. ${ }^{41}$

\footnotetext{
${ }^{41}$ Burger and Warnock (2003) look at these data from a different point of view that is entirely orthogonal to our point. They compare U.S. holdings of European bonds as a share of the total European market with U.S. holdings of Canadian (or emerging market bonds) expressed as a share of the Canadian (or EM) bond market. In Europe, where the overall bond market is much larger, they obtain a relatively small fraction.
} 
Goldstein and Turner define their measure of aggregate effective currency

mismatches $(A E C M)$ as:

$A E C M=\frac{N F C A}{E X P} * F C S H A R E$

NFCA is net foreign currency assets, EXP is exports, and FCSHARE is the foreign

currency share of total debt (both domestic and international). ${ }^{42}$ Unfortunately, the data

do not exist to compute AECM for a substantial number of countries. In particular,

information on net foreign currency assets beyond international reserves and on the

currency composition of total debt (international and domestic) are available for a limited

number of countries. For this reason, Goldstein and Turner restrict their sample to 22

countries.

It is possible to build a measure similar to $A E C M$ for a larger sample. Consider

the following index:

$M I S M A T C H=\frac{R E S-D E B T}{E X P} O S I N$

But this is due to the larger denominator. Consider a world in which the European economy and European bond market are many times larger than those of the United States. We would then see U.S. investors holding only a small fraction of total European bond issuance. But this would tell us nothing about Europe's susceptibility to original sin; it would only confirm that the European economy and bond market were very much larger than those of the United States. Thus, Table 2 in their paper, cited by Goldstein and Turner (2003) as a criticism of the original-sin view, has no bearing on the question.

${ }^{42}$ Goldstein and Turner suggest that this is a good measure of overall mismatches because besides capturing both sides of the balance sheet and considering the currency denomination of total debt, it also has substantial volatility over time and hence the potential of being a useful leading indicator of currency crises. Note that since higher levels of AECM indicate lower mismatches, when NFCA is positive they replace exports with imports. 
$R E S$ is international reserves, $D E B T$ is international debt, and other variables are defined as above. ${ }^{43}$ MISMATCH is not identical to AECM, but for the countries for which we have data on both the correlation of the two measures is $0.82(\mathrm{p}$ value $=0.000){ }^{44}$

We now augment the preceding regressions with this measure. ${ }^{45}$ To facilitate comparison we multiply MISMATCH by minus one so that a higher value indicates a higher mismatch.

Columns 4, 5, and 6 of Table 3 show that controlling for MISMATCH does not eliminate the correlation between original sin and our three measures of exchange rate flexibility. If anything the effect of OSIN becomes stronger. MISMATCH has a significant effect on RESM2 (the ratio of reserves to M2), but this is to be expected because reserves are used in the construction of MISMATCH. There is no significant correlation between MISMATCH and either LYS or RVER, our two measures of exchange rate policy. Columns 3 and 4 of Table 4 similarly show that MISMATCH is not significantly correlated with the volatility of growth or capital flows. ${ }^{46}$

The last column of Table 5 checks whether controlling for MISMATCH affects the relationship between original sin and credit ratings. The significance of MISMATCH

${ }^{43}$ We could also measure mismatches as: $\frac{R E S-D E B T^{*} O S I N}{E X P}$. This alternative definition makes more sense to us, but the one in the text is closer to that used by Goldstein and Turner. In practice, the two measures are highly correlated. The results discussed below do not change if we use one measure instead of the other.

${ }^{44}$ In particular, MISMATCH does not capture net international assets or measure the currency composition of total debt.

${ }^{45}$ The present expanded sample includes 20 of Goldstein and Turner's 22 countries. (Some of the data needed to construct the mismatch proxy for China and Taiwan are not available.)

${ }^{46}$ Including this variable in the regressions also reduces the explanatory power of original sin; with a $p$ value of $0.14, O S I N$ is no longer statistically significant at conventional levels. At the same time, controlling for MISMATCH substantially raises the point estimate of OSIN. This suggests that the drop in statistical significance is due to the fact we are now forced to use a smaller sample. If we estimate equations 1 and 2 on the same sample of equations 3 and 4 we find results similar to those of columns 3 and 4: the point estimates of original sin increase but the coefficients are not statistically significant. 
indicates that countries with large stocks of international reserves and small international debts have better ratings, other things equal, these variables providing widely utilized rules of thumb of the rating agencies. But controlling for MISMATCH leaves the point estimate and significance of the coefficient on $O S I N$ unchanged. An interpretation is that credit ratings are sensitive both to whether or not a country can borrow abroad in its own currency and how effectively it manages any currency mismatches that result from its inability to do so.

Debt intolerance. Recall that Reinhart, Rogoff and Savastano (2003) define debt intolerance as the inability of emerging markets to manage external debts that are manageable for advanced countries. They operationalize it as the relationship of external debt (scaled by GDP or exports) to a measure of country risk (credit ratings).

We already included the debt/GDP and debt/revenue ratios in the credit-rating regressions reported earlier in this section, along with OSIN. There we found that both original sin and debt ratios matter for credit ratings. ${ }^{47}$ We can generalize this analysis by allowing the debt ratio to have a different impact on credit ratings in advanced and developing countries. Let $D E_{-} G D P^{*} I N D$ and $D E_{-} R E^{*} I N D$ denote the effect of the debt/GDP and debt/tax revenue ratios in the advanced economies and $D E \_G D P^{*} D E V$ and $D E \_R E^{*} D E V$ the effect of these same ratios in developing countries. Table 7 shows that that the impact of original sin on credit ratings is robust to this extension. When we add a separate intercept for developing countries to avoid loading all other respects in which advanced and developing countries differ into the $D E_{-} G D P * D E V$ and $D E \_R E V^{*} D E V$ terms, original sin remains significant and important, while there is again

\footnotetext{
${ }^{47}$ As does MISMATCH - again see Table 5 above.
} 
no difference in the elasticity of credit ratings with respect to the external debt ratio in developing versus advanced economies.

We constructed two alternative measures of debt intolerance and checked whether adding them to our regressions for exchange rate flexibility diminishes the impact of original sin. The first measure, $D I 1$, is non-official external debt (scaled by GDP) relative to $R A T I N G .^{48}$ The second one, DI2, is the domestic and external public debt (again scaled by GDP) relative to RATING. Table 8 asks whether controlling for debt intolerance, so measured, affects the correlation between original sin and exchange rate flexibility. ${ }^{49}$ It turns out that these proxies for debt intolerance have little additional impact on exchange rate flexibility, while the results for original sin are basically unchanged..$^{50}$

Table 9 examines the implications of adding these alternative measures of debt intolerance to our analysis of the volatility of growth and capital flows. Their addition does not diminish the impact of original sin on the volatility of either GDP growth or capital flows. In contrast, neither measure of debt intolerance has a significant impact on the volatility of GDP growth.

There is some evidence that debt intolerance is significantly correlated with the volatility of capital flows. But when we separate the variable into its two components (debt ratio and credit rating), we find that most of the explanatory power resides with the denominator (see columns 9-11 of Table 9). Total external debt over GDP and

\footnotetext{
${ }^{48}$ Our measure differs from that of Reinhart, Rogoff and Savastano in that we include both public and private debt while excluding official instead of concessional debt.

${ }^{49}$ When we use $D I 1$, we run regressions both including and excluding external debt over GDP from some specifications on the grounds that this variable is in the numerator of $D I 1$.

${ }^{50}$ The debt intolerance measure has additional impact on exchange rate flexibility only in two specifications.
} 
government debt over GDP are never statistically significant (total debt has also the wrong sign). This is telling us that countries with low credit ratings have relatively volatile capital flows, which is not surprising given the bi-directional causality between the variables. ${ }^{51}$

\section{Additional Issues}

In this section we consider a number of additional issues from the recent openeconomy balance-sheet literature.

A. Hedging. Efforts to measure an economy's vulnerability to balance-sheet effects using the value of securities issued abroad that are denominated in foreign currencies can mislead if swaps and other derivative transactions are used to hedge currency exposures. ${ }^{52}$ The limited availability of information on derivative transactions is thus an impediment to empirical work in this area. ${ }^{53}$

Of course, if foreigners hold no financial claims on a country that are denominated in its own currency (the extreme form of origin sin that appears to afflict fully half of the countries considered in the appendix to Eichengreen, Hausmann and Panizza 2003a), then its aggregate foreign currency exposure cannot be hedged as a matter of definition. ${ }^{54}$ For residents of the country to swap out of their aggregate

\footnotetext{
${ }^{51}$ In addition, we reject the null that the two coefficients enter with equal and opposite signs, as suggested by the debt-intolerance hypothesis. This is shown in the last two rows that check whether the sum of the rating and debt coefficients (evaluated at the mean of the respective variables) is equal to zero and strongly reject the hypothesis.

${ }^{52}$ Simply tabulating the value of foreign-currency-denominated securities sold to foreigners will not produce a measure of gross foreign currency exposure, for example, if domestic issuers use derivative transactions to swap out of the foreign currency.

${ }^{53}$ To put the point another way, the difficulty of tracking off-balance-sheet transactions creates problems for the balance sheet approach.

${ }^{54}$ Goldstein and Turner (2003) state that the "original sin hypothesis" assumes that all emerging markets are alike in terms of their ability to hedge foreign exposures. If they are alluding to our work, then this is
} 
currency mismatch, there must be someone on the other side of the swap. If foreigners are unwilling to hold local currency exposure, they will be unwilling to purchase swaps, and the issuing country will be unable to hedge its aggregate foreign currency exposure. Firms can use hedges to pass around foreign currency exposures like a hot potato, but as a group they cannot shed it if foreign investors are unwilling to hold it. ${ }^{55}$ If that exposure is reallocated domestically in efficient ways - if it is transferred at a price to firms in the strongest position to manage the associated risks (from firms producing nontradables to firms producing tradable goods for example) - then the effects of original sin may be mitigated. ${ }^{56}$ But the effects are analytically distinct from the phenomenon itself. ${ }^{57}$

\section{B. Measuring Currency Mismatch. In the case of aggregate currency}

mismatches, it is important to net a country's international reserves and other foreigncurrency-denominated financial assets from gross external liabilities denominated in foreign currency. It may or may not be important to also include domestic debts denominated in foreign currency. If there is no foreign participation in domestic debt markets, then the currency denomination of domestic debts has no bearing on

\footnotetext{
an erroneous description. To the contrary, we emphasize that those countries with the most severe cases of original sin (all of the country's debt to foreigners is denominated in foreign currency) are by definition unable to hedge their exposures in the aggregate, while others may be able to do so to some extent.

55 Alternatively, the government can assume the risk. Bonomo, Martins, and Pinto (2003) suggest that after the Brazilian devaluation of 1998 the government became the ultimate source of hedging. In this case, then, the mismatch was transferred from the private to the public sector.

${ }^{56}$ Goldstein and Turner (2003) criticize our OSIN measure for failing to distinguish the allocation of currency risk between traded and nontraded goods producing sectors. This confuses the effects of OSIN with its magnitude (in effect, it fails to distinguish between the left and right hand side variables in our regression equations). We return to this point below. It also confuses their concern, currency mismatches, with our's, the currency composition of the gross external debt. This criticism is also disingenuous because Goldstein and Turner themselves have no information on the distribution of aggregate currency exposures between the traded and nontraded goods producing sectors for the sample of 22 countries.

${ }^{57}$ If hedging had been important in the sample period for mitigating the effects of original sin, we of course would not find the strong correlation between original sin, fear of floating, capital flow and output volatility, and credit ratings that we document in the previous section.
} 
calculations of the aggregate currency mismatch, insofar as one resident's domestic dollar (peso) liability is another resident's domestic dollar (peso) asset. ${ }^{58}$

With the growing participation of foreign investors in local emerging bond markets, it becomes increasingly problematic to neglect the currency denomination of issues on the latter. But it cannot simply be assumed that all local currency issues are local currency denominated. Burger and Warnock (2003, n.9) observe that "BIS data on domestic bonds is not collected at the security level but should (emphasis added) contain only local-currency denominated bonds placed locally; for Argentina and Peru, however, it contains some foreign currency issues..." Burger and Warnock recategorize the relevant bonds for these two countries. Unfortunately, it is probable that there also exist other foreign currency issues in the BIS data. There is also the fact that some fraction of emerging market debt securities placed locally is indexed to the exchange rate rather than denominated in foreign currency, creating the same problems as foreign-currencydenominated debt from the point of view of the balance-sheet literature.

Concentrating solely on the currency composition of financial assets and liabilities also ignores natural hedges. The same exchange rate change that increases the cost of servicing foreign-currency denominated external obligations may increase the demand abroad for the exports of the indebted country and hence its capacity to meet its debt service obligations. This observation has encouraged some students of currency mismatches to normalize net foreign currency denominated financial debt by exports, as we saw in equation 2 above.

\footnotetext{
${ }^{58}$ The currency denomination of domestic debts may still have important implications for the financial vulnerability of individual firms and banks, as noted above (if, for example, foreign-currency net liabilities are concentrated among producers of nontradables). But this vulnerability will not be picked up by aggregate measures of the currency mismatch.
} 
But normalizing by exports, whether gross or net, confuses stocks with flows. ${ }^{59}$ What is relevant when the exchange rate changes is the (increase in the) flow of export revenues relative to the increase in the flow of debt service costs, not a comparison of stocks of financial assets with flows of export receipts. Comparing the flow of export receipts with the flow of interest payments on foreign currency denominated financial assets would be more appropriate in this context. ${ }^{60}$

Normalizing the stock of net external debt denominated in foreign currency by exports also conflates the extent of the mismatch with its effects. A country that exports less will almost certainly find it harder to undertake the macroeconomic adjustment needed to contend with the adverse balance sheet effects of exchange rate depreciation. But the impact of an exchange rate change when there is a currency mismatch is different from the size of the mismatch. ${ }^{61}$ A measure like eq. 2 might be defended as a leading indicator of the potential severity of potential mismatch problems, but this would be quite different from saying that it is an adequate measure of the extent of mismatches.

C. The Domestic Aspect. Eichengreen and Hausmann (1999) used original sin to refer to both the difficulty emerging markets have in borrowing abroad in their own currencies and the difficulty that many of them also experience at borrowing at home, in local currency terms, at long maturities and fixed rates. Countries suffering from both

\footnotetext{
${ }^{59}$ At the level of abstraction, Goldstein and Turner (2003) distinguish a flow measure of mismatches from a stock measure of mismatches, but this distinction is not maintained when they turn to empirics and develop the measure reproduced in eq. 2 above.

${ }^{60}$ In addition, the same distinction between gross and net foreign currency denominated financial obligations emphasized elsewhere applies to exports as well; the (increase in) export revenues should presumably be net (of the increase in import spending) rather than gross.

${ }^{61}$ In a regression framework, an appropriate way of controlling for the fact that the same currency mismatch may have larger effects on macroeconomic variables in less open economies is to interact the mismatch variable with a measure of openness (also controlling separately for openness, since openness may also affect those macroeconomic variables through non-balance-sheet channels), not to construct a variable that conflates the extent of the mismatch with the likely magnitude of its effects.
} 
problems will find it particularly difficult to cope with adverse shocks. If they allow the currency to depreciate in response, they will be hammered by the balance-sheet effects of the aggregate currency mismatch. But if they attempt to support the currency by raising interest rates, firms and banks will have their financial situation destabilized by the rise in the short term interest rate, given the absence of long-term, fixed-rate debt. ${ }^{62}$

In subsequent work we narrowed our definition, focusing on the difficulty that emerging markets experience in borrowing abroad in their own currencies, reflecting evidence that, with sufficient time and effort, it has become possible for some of them to develop the capacity to place longer-term domestic-currency issues with local residents. IMF (2003) reports that local corporate bond issues in emerging markets grew by a factor of ten between 1997-99 and 2000-1 and that local bond markets have been the dominant source of funding for the public sector in emerging markets as a class. The role of domestic bond issues in corporate funding has been particularly important in Latin America, where local bond issues nearly equaled the sum of international issues of bonds, equities and syndicated lending in the period 1997-2001.

At the same time, a substantial number of domestic bond placements are indexed to the exchange rate, as noted above, rendering them indistinguishable from a currencyrisk point of view foreign-currency denominated issues. A substantial share of the remainder is indexed to the short-term interest rate, thereby providing no protection from interest rate hikes. Still, emerging markets, especially in Asia, have made some progress in issuing long-dated bonds that, when indexed at all, are indexed to slowly-moving

\footnotetext{
${ }^{62}$ This was the situation in which Asian banks that had funded themselves by incurring short-term obligations found themselves in 1997 and why the dilemma of whether to let the exchange rate go or to defend it with interest rate hikes was a no-win situation.
} 
variables like inflation rather than to financial variables like exchange rates and shortterm interest rates that respond instantaneously to shocks. ${ }^{63}$

Figure 1 shows a scatter plot of our original sin measure (OSIN) versus a measure of the ability to issue domestic currency long-term fixed-rate debt, or "domestic original $\operatorname{sin"}(D S I N)$, for all countries for which we have been able to construct both measures. Our main source of information on domestic original sin is J.P. Morgan's (1998, 2000, 2002) Guide to Local Markets, which reports detailed information on domestically-traded public debt for 24 emerging market countries. We divide outstanding government bonds into 5 categories: (i) long-term domestic currency fixed rate (DLTF); (ii) short-term domestic currency fixed rate (DSTF); (iii) long-term (or short-term) domestic currency debt indexed to interest rate (DLTII); (iv) long-term domestic currency debt indexed to prices (DLTIP); and (v) foreign currency debt (FC). We define domestic original sin as:

$$
D S I N=\frac{F C+D S T F+D L T I I}{F C+D L T F+D S T F+D L T I I+D L T I P}
$$

This definition focuses on both foreign currency debt and domestic currency short-term debt (or long-term but indexed to the interest rate). ${ }^{64}$

Note that there are a number of countries with low levels of DSIN but high levels of OSIN, such as Chile, Israel, India, Hungary and Thailand. Contrary to the conjecture

\footnotetext{
${ }^{63}$ Thus, in our empirical work we classify countries as not suffering from the domestic aspect of original sin only when they have issued significant amounts of domestic-currency debt that is not floating rate, short-term or dollar indexed. In one of our measures, we include debt that is indexed to the consumer price index, a more slowly moving non-financial variable.

${ }^{64} \mathrm{We}$ only have information on traded debt (and mostly public debt). Hence, if a country has a market for long-term fixed rate bank loans but no market for long-term fixed rate debt instruments, our indexes may overestimate original sin. If, on the other hand, a country has a market for long-term fixed rate debt instruments but no market for long-term fixed rate bank loans, our indexes will provide a lower bound for original sin. The data in Figure 1 are for December 2001 with the exception of Argentina (the data refer to 1998) and Egypt (the data refer to 2000).
} 
of Reinhart, Rogoff and Savastano (2003), it is not obvious that the domestic and international aspects of original sin are determined by identical sets of factors. ${ }^{65}$

There is now a substantial literature on the development of domestic bond markets and on the relevant policy initiatives (see Harwood 2000 and Herring and Chatusripitak 2000). Steps for developing domestic bond markets include running stable macroeconomic policies, strengthening payment and settlement systems, and using regulation to encourage transparency on the part of market participants. But what is striking is that the same emerging markets that have made progress in these areas and thus have been rewarded with faster domestic bond market development have made less progress in acquiring the capacity to borrow abroad in their own currencies. This is the observation that led us to more narrowly focus our definition of original sin. It is what has led us to conjecture that there is something about the structure of foreign demand for claims denominated in the local currency contributing to the problem of original sin. ${ }^{66}$ Even if domestic reforms that help to promote the development of local markets do not eliminate original sin, might they not eliminate the main reason for worrying about it by eliminating the need for countries to borrow abroad? With well-developed domestic financial markets, the argument might run, it will become possible to finance domestic investment out of domestic savings, with no need for recourse to foreign finance. However, such a conclusion would minimize the benefits of international borrowing (and lending) for smoothing consumption, diversifying risk, and augmenting investment where

\footnotetext{
${ }^{65}$ On the other hand, there are no countries with high levels of DSIN and low values of OSIN. This supports the idea that resolving the domestic aspects of original sin is a necessary condition for addressing the international aspect. Hausmann and Panizza (2003) show that the determinants of DSIN and OSIN are empirically quite different, with inflation history and institutions playing a larger role in the former and country size playing an important and robust role in the latter.

${ }^{66}$ We consider this possibility more systematically below.
} 
appropriate. Countries like the United States with well-developed domestic financial markets still make use of the capital account for these purposes. It is not obviously the case, in other words, that well-developed domestic financial markets render the foreign finance superfluous. ${ }^{67}$ To the contrary, the case for having safe access to international finance remains compelling.

The question is what safety requires. Potential borrowers must pursue macroeconomic, financial and institution reforms in order to be able to deploy foreign funding productively and become attractive destinations for international capital flows. But potential borrowers and lenders must also be able to address the sources of the reluctance of foreign investors to hold claims denominated in the currencies of emerging markets in order to create an attractive balance between the risks and returns of borrowing abroad. It is to this problem that we now turn.

D. Reflections on Causes. In Eichengreen, Hausmann, and Panizza (2003b) we examine several potential explanations for original sin. Although the level of development, monetary credibility, and the quality of institutions may play a role, the evidence there suggests that these variables by themselves cannot account for the widespread nature of the phenomenon. Country size is the only variable analyzed that is both statistically and economically significant as a determinant of original sin. It is this finding that leads us to formulate an explanation for original sin based on the costs and returns to portfolio diversification at the global level.

\footnotetext{
${ }^{67}$ Goldstein and Turner (2003, p.21) write that they find unpersuasive "the view (implicit in the OSH [original sin hypothesis]) that any analysis of the path to reduced financial fragility and higher economic growth in emerging markets should concentrate exclusively on external sources of finance." This position is certainly not implicit in our work. Rather, our position is that domestic bond market development does not eliminate the argument for international finance. If we have focused on measures to enhance access to international finance, this is because this aspect of the problem is particularly difficult to solve (as explained in the text).
} 
Here we summarize our previous empirical analysis and consider some additional wrinkles. ${ }^{68}$ Country size is measured as the principal component of the log of total GDP, $\log$ of total trade and the log of total domestic credit. Column 1 of Table 10 shows that country size is negatively related to original sin. A variety of sensitivity analyses support the conclusion that size is important in regressions seeking to explain original sin. We therefore control for country size in all of the empirical analysis that follows.

Table 2 above suggested that original sin varies between financial centers, the Euroland countries, other advanced economies, and developing countries. In the analysis that follows we therefore control for membership in these country groups by including a vector of country-group variables (where developing country is the omitted alternative). Table 2 shows that these fixed effects are quite important. ${ }^{69}$

In column 2 of Table 10 we add per capita GDP as a measure of economic development. Both this variable and country size are negatively correlated with original sin, although only size is significantly different from zero at standard confidence levels.

In column 3 we consider inflationary history as a measure of monetary credibility. Our variable is constructed as the average of log inflation over the last 20 years in an effort to capture any lingering effects of policies long past. While countries with

\footnotetext{
${ }^{68}$ Since our dependent variable ranges between 0 and 1 , all the regressions are estimated by weighed Tobit. In Eichengreen, Hausmann, and Panizza (2003b) we show that the results are robust to alternative estimation techniques. As before, all variables are measured as 1993-1998 averages (except where explicitly noted to the contrary).

${ }^{69}$ Not including these fixed effects, which subsequent analysis shows to be important, may therefore bias our results. Doing so may attribute to a country's policies the effects of its status as a financial center. Or it may attribute to, say, inflation the effect of all the characteristics of a country that are associated with its industrial-country status. In the interest of completeness, we show below how the results change when we omit these country-group fixed effects and provide an interpretation of the differences. It turns out that they do not change very much.
} 
histories of more inflation appear to have more original sin, the effect does not approach statistical significance at standard confidence levels. ${ }^{70}$

Columns 4 and 5 test the hypothesis that original sin is the consequence of debt intolerant countries borrowing too much. ${ }^{71}$ Regressing original sin on the public debt/GDP ratio, we find that the coefficient on the latter is insignificantly different from zero. To capture the possibility that the impact of the same debt/GDP ratio is greater in developing countries, column 5 allows the impact of debt to differ between them (where $D E \_G D P^{*} D E V$ is the debt/GDP ratio interacted with a developing country dummy and $D E \_G D P^{*} I N D$ is the same ratio interacted with an industrial country dummy, as before). While we obtain a positive coefficient on debt/GDP for developing countries and a negative coefficient for the advanced countries, neither coefficient differs significantly from zero at standard confidence levels.

Columns 6, 7, 8, and 9 consider institutional quality (using index of rule of law developed by Kaufmann et al. 1999). The Tobit regression in column 6 produces a negative effect of institutions on original sin, but one that is again statistically insignificant at standard confidence levels. Recent papers (e.g. Sachs 2001, Hall and Jones 1999, Acemoglu, Johnson, and Robinson 2001) suggest focusing on geography and colonial settlement patterns as ways of identifying the exogenous component of institutions. When we instrument institutions with distance from the equator (column 7),

\footnotetext{
${ }^{70}$ Shorter lags of inflation only strengthen this result. This finding is also robust to a variety of sensitivity analyses. When we replace average inflation with the log of maximum inflation over the period, we again find no significant relationship with original sin. To test potential non-linearities in the relationship between inflation and original sin, we also experimented with both the average log of inflation and its square. In this case, neither of the coefficients on inflation is significant. Alternatively, we use the principal component of average inflation and maximum inflation and again finds no significant correlation with original sin (results are reported in the appendix of Eichengreen, Hausmann, and Panizza, 2003b).

${ }^{71}$ This would make debt intolerance the fundamental cause of the financial-fragility problem and original sin one of its symptoms.
} 
we find that the former is still not statistically significant. When we instrument institutions with the log of settler mortality (column 8), there again appears to be no effect. Column 9, where we estimate this equation by OLS but using the same sample as in column 8 , suggests that this is not due to the limited number of countries for which we have data on settler mortality.

In column 10 we consider the role of financial development. ${ }^{72}$ We find a negative but not statistically significant relationship between original sin and financial development as measured by the ratio of domestic credit to GDP. To control for the endogeneity of financial development, we next instrument the domestic credit/GDP ratio with the origin of the legal system. We follow La Porta et al. 1998, using a dummy variable that takes a value of one in countries following the French civil law tradition. Column 11 shows that controlling for endogeneity does not affect the result.

Column 1 of Table 11 includes all of these variables in the same equation. We consider these to be the definitive hypothesis tests. Again, we find that the coefficient on SIZE is negative and significantly different from zero at conventional confidence levels. In addition, GDP per capita and institutions are also statistically significant. But while GDP per capita has the expected negative sign, institutions have a positive coefficient, as if countries with worse institutions suffer less from original sin. This appears to be due to the high correlation between GDP per capita and rule of law (0.83). A Wald test suggests that the two variables are not jointly significant $(\mathrm{p}$ value $=0.14)$, and when they are entered one at a time (in columns 2 and 3) neither of them is statistically significant. The

\footnotetext{
${ }^{72}$ Tirole (2002) provides a political economy explanation for a possible relationship between original sin and the development of the domestic financial system.
} 
last column shows that the results do not change if we instrument institutions with latitude. $^{73}$

Tables 10 and 11 thus suggest that original sin is robustly related to country size and to countries' status as financial centers, advanced economies or emerging markets but that it is only weakly related to institutional variables like rule of law and measures of policy like inflation and fiscal history.

When we eliminate the country group dummies, in Table 12, inflation history matters when entered by itself, as in column 2. There is also some evidence of an effect of institutions (whether modeled as exogenous or instrumented using settler mortality) in columns 5 and 7. There is more evidence of the importance of financial development (see column 9), although the correlation between financial development and original sin is not robust to instrumenting financial development with the origin of the legal code (see in column 10).

But when we include proxies for the competing hypotheses simultaneously, in Table 13, the results are essentially identical to before. Column 1 shows that SIZE and GDP per capita are statistically significant. Column 2 allows institutions to be endogenous (we use latitude as an instrument) and shows that only size remains statistically significant. Column 3 treats both rule of law and domestic credit over GDP as endogenous (again we instrument domestic credit over GDP with the origin of the legal code). Once more, only SIZE enters with a coefficient that is statistically distinguishable from zero at standard confidence levels. ${ }^{74}$

\footnotetext{
${ }^{73}$ When we instrument institutions with settler mortality, none of the explanatory variables matters (which presumably reflects the limited sample size).

${ }^{74}$ If one ignores the fact that the coefficients on the policy and institutional variables go to zero when they are included in the equation simultaneously (which will be comfortable only for readers with strong priors),
} 
What might account for the fact that it is mainly large countries that seem to be able to issue foreign debt in their own currencies and for the concentration of the world's portfolio in few currencies? While each additional currency adds opportunities for diversification, it does so with decreasing marginal benefits. In a world with transactions costs (that increase with the number of currencies in which investors take positions), the optimal portfolio will therefore have a finite number of currencies.

Imagine the following situation. ${ }^{75}$ There are two countries: one has $\mathrm{N}$ trees while the other has 1 tree. All trees are identical in their expected income and its variance; the large country just has more of them. Shocks to each tree are uncorrelated. Assume that the exchange rate moves with the realization of relative output. If there were no transactions costs of investing abroad, then it would be optimal to hold a globally diversified portfolio: the large country would invest $1 /(\mathrm{N}+1)$ of its wealth in the small country, while the latter would invest $\mathrm{N} /(\mathrm{N}+1)$ in the large country. Now introduce costs to international transactions. If all countries were of size 1 , then the presence of transaction costs would not affect the composition of the world portfolio. But if country size differs, then the benefits of international diversification will be greater for the small country than for the large one. There will be less appetite in the large country to hold the currency of the small country, while there will still be a large appetite for the small

then the contrast between Tables 11 and 12 would suggest an interpretation like the following. When the fixed effects for financial centers, advanced economies, and emerging markets are included in the equation, they absorb the cross-group variation in the data. The coefficient on a variable like, say, inflation or rule of law then picks up only the within-group variation. This is telling us that if we could transform Colombia into Canada and give the former more favorable policy history and institutions of the latter (along with is greater proximity to large markets, etc.) overnight, then we would also give it a greater ability to borrow abroad in its own currency. On the other hand, transforming Colombia into Chile (in terms of the quality of policies and institutions) would do little to enhance its ability to borrow abroad in its own currency. This is not to reject the importance of sound policies and institutional development. But it does suggest that the standard advice to this effect is not going to solve the problem of original sin that plagues emerging markets anytime soon.

${ }^{75}$ We are indebted to Roberto Rigobon for yet unpublished joint work on this idea. 
country to hold the assets of the large one. This is to say, large countries offer significant diversification possibilities, while small countries do not. If the transaction costs associated with international diversification are the same for investors in both countries, then the world will choose to invest in a few large currencies. Notice that this is through no fault of the small country, but a consequence of the existence of cross-border costs and asymmetries in size and diversification.

An implication of this view is that even if we identify characteristics that have allowed a few small countries to issue external debt in their own currencies - say, like South Africa, New Zealand or Poland - it would be a fallacy of composition to assume that if other small countries acquired those same characteristics then they too would make it into the world portfolio. Each successful country may limit the chances of the others, given declining marginal benefits of diversification.

A further implication of this approach is that country size matters for original sin. Some countries have an advantage in shedding original sin because the large size of their economies and currency issue makes it attractive as a component of the world portfolio. In contrast, the currencies of small countries add few diversification benefits relative to the additional costs they imply.

Country size can explain why large countries like the US and Japan do not suffer from original sin. But what about Switzerland and, for that matter, the UK? Note that the financial-center dummy remains large and significant even after controlling for country size. This is another way of saying that the UK and Switzerland have become immune from the problem. But if becoming a financial center is evidently another way of shedding original sin, this is easier said than done. Clearly, countries that either are or 
were major commercial powers (e.g. the United States, Britain in the past) have a leg up. In addition, some countries have been able to gain the status of financial centers as a quirk of history or geography. ${ }^{76}$ Network externalities giving rise to historical path dependence have worked to lock in their currencies' international status: once the Swiss franc was held in some international portfolios and used in some international transactions, it became advantageous for additional investors and traders to do likewise. And because Britain was the world's leading industrial, trading and lending nation once upon a time, sterling acquired its position as a prominent currency for the denomination of international claims, a luxury that the country enjoys to this day, albeit to a lesser and declining extent. These observations are related to the literature on the determinants of key currency status (Kiyotaki, Matsuyama and Matsui 1992), which explains the dominance of a small number of currencies in international markets as a function of network externalities and transactions costs. This literature does not deny that additional countries cannot gain admission to this exclusive club, but it suggests that they face an uphill battle.

All this suggests that the global portfolio may be concentrated in a very few currencies for reasons at least beyond the control of the excluded countries.

\section{Conclusion}

In this paper we have contrasted three concepts widely utilized in the recent literature on emerging market debt. Two of them - "original sin" and "debt intolerance" - attempt to explain the same phenomenon, namely the volatility of emerging market

\footnotetext{
${ }^{76}$ For example Switzerland, a mountainous country at the center of Europe that was hard to take over and also small enough to retain its neutrality, became a convenient destination for foreign deposits.
} 
economies and the difficulty that these countries have in servicing and repaying their external debts. The debt-intolerance school traces the problem to institutional weaknesses of emerging-market economies that in turn lead to weak and unreliable policies. It suggests that these countries' histories have bequeathed a situation where they find it difficult to run strong policies.

The original-sin school traces the problem instead to the structure of global portfolios and international financial markets. It suggests that emerging-market economies are volatile because they find it difficult to denominate their obligations in units that better track their capacity to pay, such as the domestic currency or the domestic consumption basket. It suggests that this constraint derives in part from the structure of international portfolios and the operation of international financial markets. It points to forces that concentrate international portfolios and markets in a few major currencies the dollar, euro, yen, pound and Swiss franc - and to the evidently limited appetite of international investors for adding additional currencies to their portfolios.

In contrast, the literature on currency mismatches, as we read it, is concerned with the consequences of these problems. It emphasizes balance-sheet mismatches that may arise from either the weak policies pointed to by the debt-intolerance literature or from the difficulty emerging markets experience when attempting to place domestic-currencydenominated debt with foreign investors pointed to by work on original sin. It is concerned with how these consequences are managed by the macroeconomic and financial authorities. 
Thus, it is not helpful when these terms are used interchangeably. The hypotheses and problems to which they refer are analytically distinct. Using them synonymously is an unnecessary source of confusion.

We close with a suggestion each for investigators concerned with currency mismatches, debt intolerance and original sin. For those concerned with currency mismatches, the challenge is to show that mismatches can be measured with the precision needed to systematically test hypotheses regarding their causes and consequences. Absent comprehensive information on the currency denomination of assets and liabilities, swaps and other derivatives, it is difficult to measure the currency composition of a country's external assets and liabilities reliably. The same problem follows from the absence of information on foreign holdings of domestic placements and on the presence or absence of exchange-rate indexation clauses in those holdings. Once the concept is adequately operationalized, the challenge will be to model its determinants as well as its consequences - since the extent of the mismatch is a choice variable of, among others, the government, which chooses whether or not to restrict foreign borrowing and to insure against the consequences by accumulating reserves - and to analyze the two aspects in a consistent way.

For those concerned with debt intolerance, the challenge is to establish the existence of links between past policies and current outcomes and to document the mechanisms through which they act. Reinhart, Rogoff and Savastano (2003) suggest that the fact that the same countries have defaulted repeatedly over a period of centuries reflects the corrosive impact of past policies on their financial markets and tax systems today and through that channel on their current management of external obligations. A 
correlation between past defaults and current defaults is insufficient to establish this case.

That correlation could reflect any omitted variable that matters persistently for debtservicing difficulties and is slow to change over time. ${ }^{77}$ The challenge is thus to show that past default plays a causal role in the development of financial markets and tax systems, after controlling adequately for other determinants of their development, and that the structure of fiscal and financial systems in turn matters for current debt-servicing outcomes, after similarly controlling for their other determinants.

For those concerned with original sin, the challenge is to document the distortions in global financial markets that make it difficult to get international investors to add more currencies to their portfolios. In previous work we have speculated that most of the benefits of international portfolio diversification can be obtained by building portfolios limited to a handful of currencies. If there are fixed transaction and management costs associated with including additional currencies, then the diversification benefits of adding more may be dominated by these costs. Here, shedding light on the obstacles to getting international investors to holding additional currencies in their portfolios is the principal challenge to research.

\footnotetext{
${ }^{77}$ As we noted above, two candidates are the commodity composition of exports, which affects the volatility of the terms of trade, and the persistent difficulty that the same relatively small, less developed countries have had in getting their currencies added to the global portfolio.
} 


\section{References}

Acemoglu, Daron, Simon Johnson and James Robinson (2001), "The Colonial Origins of Economic Development: An Empirical Investigation," American Economic Review 91, pp.1361-1401.

Aghion, Philippe, Philippe Bacchetta, and Abhijit Banerjee (2000), "Currency Crises and Monetary Policy in an Economy with Credit Constraints," mimeo, University College London.

Bayoumi, Tamim and Barry Eichengreen (1998a), "Optimum Currency Areas and Exchange Rate Volatility: Theory and Evidence Compared," in Benjamin Cohen (ed.), International Trade and Finance: New Frontiers for Research, Cambridge: Cambridge University Press, pp.184-215.

Bayoumi, Tamim and Barry Eichengreen (1998b), "Exchange Rate Volatility and Intervention: Implications from the Theory of Optimum Currency Areas," Journal of International Economics 45, pp.191-209.

Blattman, Christopher, Jason Hwang and Jeffrey Williamson (2003), “The Terms of Trade and Economic Growth in the Periphery, 1870-1938," NBER Working Paper no.9940 (September).

Bonomo, Marco, Betina Martins, and Rodrigo Pinto (2003) "Debt Composition and Balance Sheet Effects of Exchange Rate and Interest Rate Volatility in Brazil: A FirmLevel Analysys," mimeo Fundaçaop Getulio Vargas.

Burger, John and Francis Warnock (2003), "Diversification, Original Sin, and International Bond Portfolios," International Finance Discussion Paper no. 755, Board of Governors of the Federal Reserve System, Washington, D.C.

Caballero, Ricardo, Kevin Cowan and Jonathan Kearns, "Reducing External Vulnerability through Financial Development: Lessons from Australia," unpublished manuscript, MIT, Interamerican Development Bank, and Reserve Bank of Australia.

Calvo, Guillermo, Alejandro Izquierdo, and Ernesto Talvi (2002) "Sudden Stops, the Real Exchange Rate and Fiscal Sustainability," Inter-American Development Bank, Research Department, Working Paper 469.

Céspedes, Luis Felipe, Roberto Chang and Andrés Velasco (2002), "IS-LM-BP in the Pampas," unpublished manuscript, Harvard University

David, Paul (2001), "Path Dependence, its Critics and the Quest for 'Historical Economics,", in Pierre Garrouste and Stavros Ionnides (eds), Evolution and Path Dependence in Economic Ideas: Past and Present, Cheltenham: Edward Elgar, pp.15-40. 
Eichengreen, Barry (2002), Financial Crises and What to Do About Them, Oxford: Oxford University Press.

Eichengreen, Barry and Ricardo Hausmann (1999), "Exchange Rates and Financial Fragility," in New Challenges for Monetary Policy, Kansas City: Federal Reserve Bank of Kansas City, pp.329-368.

Eichengreen, Barry, Ricardo Hausmann and Ugo Panizza (2003a), "The Pain of Original Sin," in Barry Eichengreen and Ricardo Hausmann (eds.), Debt Denomination and Financial Instability in Emerging-Market Economies, Chicago: University of Chicago Press (forthcoming).

Eichengreen, Barry, Ricardo Hausmann and Ugo Panizza (2003b), "The Mystery of Original Sin," in Barry Eichengreen and Ricardo Hausmann (eds.), Debt Denomination and Financial Instability in Emerging-Market Economies, Chicago: University of Chicago Press (forthcoming).

Flandreau, Marc and Nathan Sussman (2003), "Old Sins," in Barry Eichengreen and Ricardo Hausmann (eds.), Debt Denomination and Financial Instability in EmergingMarket Economies, Chicago: University of Chicago Press (forthcoming).

Gallego, F.A. and F.L. Hernandez (2003), "Microeconomic Effects of Capital Controls: The Chilean Experience During the 1990s," International Journal of Finance and Economics 8, pp.225-254.

Gavin, Michael, Ricardo Hausmann and Leonardo Leiderman (1995), "The Macroeconomics of Capital Flows to Latin America: Experience and Policy Issues," Working Paper no. 310, Washington, D.C.: Interamerican Development Bank.

Goldstein, Morris (1998), The Asian Financial Crisis, Washington, D.C.: Institute of International Economics.

Goldstein, Morris and Philip Turner (2003), "Controlling Currency Mismatches in Emerging Market Economies: An Alternative to the Original Sin Hypothesis," unpublished manuscript, Institute of International Economics (August).

Hall, Robert and Charles Jones (1999), "Why Do Some Countries Produce So Much More Output per Worker than Others?" Quarterly Journal of Economics 114, pp. 83-116.

Harwood, Alison, ed. (2000), Building Local Currency Bond Markets: An Asian Perspective, Washington, D.C.: International Finance Corporation.

Hausmann, Ricardo and Michael Gavin (1996), "Securing Stability and Growth in a Shock-Prone Region: The Case of Latin America," in R. Hausmann and H. Reisen, (eds.), Securing Stability and Growth in Latin America: Policy Issues and Prospects for Shock-Prone Economies. Paris: OECD. 
Hausmann, Ricardo (2003), "Good Credit Ratios, Bad Credit Ratings: The Role of Debt Structure," in G. Kopits, (ed.), Rules-Based Fiscal Policy in Emerging Markets:

Background, Analysis and Prospects. London: Macmillann (forthcoming).

Hausmann, Ricardo and Ugo Panizza (2003), "The Determinants of Original Sin: An Empirical Investigation," Journal of International Money and Finance, forthcoming.

Herring, Richard J. and Nathporn Chatusripitak (2000), "The Case of the Missing Market: The Bond Market and Why it Matters for Financial Development," ADB Institute Working Paper no. 11 (July).

International Monetary Fund (2003), Global Financial Stability Report, Washington, D.C.: IMF (March).

Jeanne, Olivier (2002) "Monetary Policy and Liability Dollarization," unpublished manuscript, International Monetary Fund.

J.P. Morgan (various years), Guide to Local Markets, New York: J.P. Morgan.

Kaufmann, Daniel, Aart Kraay and Pablo Zoido-Lobaton (1999) Aggregating

Governance Indicator. World Bank Policy Research Working Paper 2195.

Kiyotaki, Nobu, Kiminori Matsuyama and Akihiko Matsui (1992), "Toward a Theory of International Currency," Review of Economic Studies 60, pp.283-307.

Krugman, Paul (1999), "Balance Sheets, the Transfer Problem, and Financial Crises," unpublished manuscript, MIT.

La Porta, Rafael, Florencio Lopez de Silanes, Andrei Shleifer, and Robert Vishny (1998) "Law and Finance," Journal of Political Economy, 106(6): 1113-1155

Levy-Yeyati, Eduardo and Federico Sturzenegger (2000), "Classifying Exchange Rate Regimes: Deeds vs. Words," unpublished, Universidad Torcuato di Tella.

Lucas, Robert (1990), "Why Doesn't Capital Flow from Rich to Poor Countries?" American Economic Review Papers and Proceedings 80 (May), pp.92-96.

Razin, Assaf and Efraim Sadka (1999), "Country Risk and Capital Flow Reversals," unpublished manuscript, Tel Aviv University.

Reinhart, Carmen, Kenneth Rogoff and Miguel Savastano (2003), "Debt Intolerance," Brookings Papers on Economic Activity 1, pp.1-74.

Sachs, Jeffrey (2001), “Tropical Underdeveloment,” NBER Working Paper no. 8119 (February). 
Tirole, Jean (2002) “Inefficient Foreign Borrowing,' invited Lecture, LACEA meeting, Madrid, October 2002.

United States Treasury (2003), "Report on U.S. Holdings of Foreign Securities," Washington, D.C.: U.S. Department of Treasury (May). 


\section{Appendix}

Countries included in Table 1 of this paper but not included in the table B1 of Reinhart Rogoff and Savastano (2003): Austria, Barbados, Belgium, Belize, China, Cyprus, Estonia, Germany, Iceland, Kazakhstan, Latvia, Lebanon, Luxembourg, Malta, Mongolia, Oman, Russian Federation, Slovak Republic, Slovenia, Switzerland, Tunisia and United Kingdom.

Countries included in Table B1 of Reinhart Rogoff and Savastano (2003) but not included in Table 1 of this paper: Algeria, Ecuador, Egypt, Ethiopia, Ghana, Hong Kong, Ireland, Japan, Kenya, Mali, Malaysia, Nepal, New Zealand, Nigeria, Portugal, Romania, Saudi Arabia, Sri Lanka, Swaziland, Tanzania, Uruguay, Venezuela, and Zimbabwe. 
Table 1: Credit rating in Developing and Advanced Countries

\begin{tabular}{|c|c|c|c|c|c|c|c|}
\hline & $(1)$ & (2) & (3) & (4) & $(5)$ & (6) & (7) \\
\hline & RATING & RATING & RATING & RATING & RATING II & RATING II & $\begin{array}{l}\text { RATING II } \\
\text { Excluding } \\
\text { South Korea }\end{array}$ \\
\hline Debt/GDP advanced & $\begin{array}{c}4.814 \\
(2.30)^{* *}\end{array}$ & $\begin{array}{l}-2.659 \\
(1.24)\end{array}$ & & & & & \\
\hline Debt/GDP developing & $\begin{array}{c}-8.627 \\
(4.96)^{* * *}\end{array}$ & $\begin{array}{l}-3.671 \\
(2.34)^{* *}\end{array}$ & & & & & \\
\hline Developing & & $\begin{array}{c}-9.027 \\
(5.78)^{* * *}\end{array}$ & & & & & \\
\hline Debt/GDP high rating & & & $\begin{array}{c}5.783 \\
(3.10)^{* * *}\end{array}$ & $\begin{array}{r}-1.511 \\
(0.83)\end{array}$ & $\begin{array}{l}25.295 \\
(2.46)^{* *}\end{array}$ & $\begin{array}{l}1.597 \\
(0.46)\end{array}$ & $\begin{array}{l}1.597 \\
(0.46)\end{array}$ \\
\hline Debt/GDP low rating & & & $\begin{array}{c}-9.207 \\
(5.85)^{* * *}\end{array}$ & $\begin{array}{c}-4.438 \\
(3.36)^{* * *}\end{array}$ & $\begin{array}{l}-32.386 \\
(3.75)^{* * *}\end{array}$ & $\begin{array}{c}-12.266 \\
(1.62)\end{array}$ & $\begin{array}{l}-8.527 \\
(1.18)\end{array}$ \\
\hline High rating & & & & $\begin{array}{c}8.917 \\
(6.60)^{* * *}\end{array}$ & & $\begin{array}{c}33.811 \\
(6.22)^{* * *}\end{array}$ & $\begin{array}{c}36.444 \\
(6.98) * * *\end{array}$ \\
\hline Constant & $\begin{array}{c}13.999 \\
(15.60)^{* * *}\end{array}$ & $\begin{array}{c}19.757 \\
(15.27)^{* * *}\end{array}$ & $\begin{array}{c}14.138 \\
(17.51)^{* * *}\end{array}$ & $\begin{array}{c}11.028 \\
(15.03)^{* * *}\end{array}$ & $\begin{array}{c}58.449 \\
(10.69) * * *\end{array}$ & $\begin{array}{c}44.988 \\
(9.03)^{* * *}\end{array}$ & $\begin{array}{c}42.355 \\
(8.92)^{* * *}\end{array}$ \\
\hline $\begin{array}{l}\text { Observations } \\
\text { R-squared }\end{array}$ & 61 & 61 & 61 & 61 & $\begin{array}{c}45 \\
0.53\end{array}$ & $\begin{array}{c}45 \\
073\end{array}$ & $\begin{array}{c}44 \\
076\end{array}$ \\
\hline $\begin{array}{l}\text { DEG_DEV=DEG_ADV } \\
\text { DEG HR=DEG_LR }\end{array}$ & $F(1,59)=41.31$ & $F(1,58)=0.14$ & $F(1,59)=62.7$ & $F(1,58)=1.69$ & $\mathrm{~F}(1,42)=72.9$ & $F(1,41)=2.77$ & $\mathrm{~F}(1,40)=1.69$ \\
\hline & $\mathrm{P}=0.000$ & $\mathrm{P}=0.705$ & $\mathrm{P}=0.000$ & $\mathrm{P}=0.199$ & $\mathrm{P}=0.000$ & $\mathrm{P}=0.104$ & $\mathrm{P}=0.214$ \\
\hline
\end{tabular}

Tobit regressions (columns 1-4) and OLS with robust standard errors (columns 5-7).

Absolute value of $t$ statistics in parentheses

* significant at $10 \% ; * *$ significant at $5 \% ; * * *$ significant at $1 \%$ 
Table 2: Measures of original sin by country groupings (simple average)

\begin{tabular}{lcc}
\hline & $\begin{array}{c}\text { OSIN } \\
\mathbf{1 9 9 3 - 1 9 9 8}\end{array}$ & $\begin{array}{c}\text { OSIN } \\
\mathbf{1 9 9 9 - 2 0 0 1}\end{array}$ \\
\hline Financial centers & 0.07 & 0.08 \\
Euroland & 0.53 & $0.09^{*}$ \\
Other Developed & 0.78 & 0.72 \\
Offshore & 0.96 & 0.87 \\
Developing & 0.96 & 0.93 \\
LAC & 0.98 & 1.00 \\
Middle East \& Africa & 0.95 & 0.90 \\
Asia \& Pacific & 0.99 & 0.94 \\
Eastern Europe & 0.91 & 0.84 \\
* In the 1999-2001 period it is impossible to allocate the debt issued by non-residents in Euros to \\
any of the individual member countries of the currency union. Hence, the number here is not \\
the simple average, but is calculated taking Euroland as a whole. \\
Source: Eichengreen, Hausmann and Panizza (2003)
\end{tabular}


Table 3: Original Sin and Exchange Rate Volatility

\begin{tabular}{lcccccc}
\hline & $(1)$ & $(2)$ & $(3)$ & $(4)$ & $(5)$ & $(6)$ \\
\hline \multirow{3}{*}{ Original Sin } & LYS & RESM2 & RVER & LYS & RESM2 & RVER \\
& 1.503 & 0.248 & -0.801 & 2.285 & 0.357 & -1.034 \\
GDP per cap & $(3.56)^{* * *}$ & $(3.74)^{* * *}$ & $(2.02)^{* *}$ & $(3.43)^{* * *}$ & $(4.01)^{* * *}$ & $(2.12)^{* *}$ \\
& 0.302 & -0.053 & 0.027 & 0.321 & -0.047 & 0.014 \\
Openness & $(2.89)^{* * *}$ & $(1.84)^{*}$ & $(0.61)$ & $(2.53)^{* *}$ & $(1.74)^{*}$ & $(0.31)$ \\
& 0.198 & -0.014 & 1.018 & 0.129 & -0.030 & 1.046 \\
Ex debt/GDP & $(0.92)$ & $(0.41)$ & $(2.88)^{* * *}$ & $(0.60)$ & $(0.89)$ & $(2.99)^{* * *}$ \\
& 0.290 & -0.036 & -0.570 & 0.622 & 0.005 & -0.664 \\
Mismatch & $(0.96)$ & $(0.66)$ & $(2.36)^{* *}$ & $(1.13)$ & $(0.09)$ & $(2.55)^{* *}$ \\
& & & & -0.037 & -0.037 & 0.084 \\
Constant & & & & $(0.35)$ & $(2.09)^{* *}$ & $(1.22)$ \\
& -2.187 & 0.531 & 0.101 & -3.094 & 0.399 & 0.394 \\
Observations & $(1.94)^{*}$ & $(1.73)^{*}$ & $(0.17)$ & $(2.14)^{* *}$ & $(1.37)$ & $(0.56)$ \\
R-squared & 75 & 65 & 65 & 59 & 64 & 64 \\
\hline
\end{tabular}

Equations 1, and 4are estimated with weighed Tobit model. All the other equations are estimated with weighed OLS with robust standard errors.

Absolute value of $\mathrm{t}$ statistics in parentheses. * significant at $10 \%$; ** significant at $5 \%$; *** significant at $1 \%$ 
Table 4: Original Sin and GDP and Capital Flow Volatility

\begin{tabular}{lcccc}
\hline & $(1)$ & $(2)$ & $(3)$ & $(4)$ \\
\hline \multirow{2}{*}{ Original Sin } & Growth & Flows & Growth & Flows \\
& 0.011 & 7.069 & 0.016 & 9.139 \\
GDP per cap & $(1.87)^{*}$ & $(3.54)^{* * *}$ & $(1.49)$ & $(1.53)$ \\
& -0.012 & -3.242 & -0.012 & -3.265 \\
Openness & $(2.19)^{* *}$ & $(2.56)^{* *}$ & $(2.03)^{* *}$ & $(2.00)^{*}$ \\
& -0.001 & -4.250 & -0.002 & -5.136 \\
TOT volatility & $(0.14)$ & $(1.21)$ & $(0.29)$ & $(0.90)$ \\
& -0.000 & 0.221 & -0.000 & 0.201 \\
Ex debt/GDP & $(0.90)$ & $(1.08)$ & $(0.82)$ & $(0.73)$ \\
& -0.014 & 0.212 & -0.025 & -2.747 \\
Mismatch & $(1.67)^{*}$ & $(0.06)$ & $(1.64)$ & $(0.29)$ \\
& \multicolumn{5}{c}{-0.002} & -0.655 \\
Constant & 0.138 & 33.134 & $(1.18)$ & $(1.29)$ \\
& $(2.30)^{* *}$ & $(2.40)^{* *}$ & $(2.133$ & 33.181 \\
Observations & 77 & 33 & $(1.91)^{*}$ \\
R-squared & 0.41 & 0.63 & 0.33 \\
Robust t statistics in parentheses & 0.59 \\
* significant at $10 \% ; * *$ significant at 5\%; *** significant at $1 \%$
\end{tabular}


Table 5: Original Sin and Credit Ratings

\begin{tabular}{|c|c|c|c|c|c|c|}
\hline & $(1)$ & $(2)$ & (3) & (4) & $(5)$ & $(6)$ \\
\hline & RATING & RATING & RATING & RATING & RATING & RATING \\
\hline \multirow[t]{2}{*}{ Original Sin } & -5.844 & -5.642 & -5.346 & -7.202 & -7.195 & -4.949 \\
\hline & $(4.07) * * *$ & $(4.00) * * *$ & $(4.08) * * *$ & $(5.20) * * *$ & $(5.05)^{* * *}$ & $(2.90) * * *$ \\
\hline \multirow[t]{2}{*}{ Debt/GDP } & -2.426 & & -2.376 & -3.721 & -3.695 & -2.358 \\
\hline & $(2.51)^{* *}$ & & $(2.71)^{* * *}$ & $(3.79) * * *$ & $(3.66)^{* * *}$ & $(2.31)^{* *}$ \\
\hline \multirow[t]{2}{*}{ Debt/Revenues } & & -1.000 & & & & \\
\hline & & $(2.49)^{* *}$ & & & & \\
\hline \multirow[t]{2}{*}{ GDP per capita } & 2.917 & 2.670 & 2.758 & 1.618 & 1.636 & 2.992 \\
\hline & $(8.47)^{* * *}$ & $(6.15)^{* * *}$ & $(8.65)^{* * *}$ & $(4.25)^{* * *}$ & $(4.12) * * *$ & $(9.09)^{* * *}$ \\
\hline \multirow[t]{2}{*}{ Ex. Debt ratio } & 2.184 & 2.784 & 1.390 & 3.546 & 3.617 & 5.309 \\
\hline & $(1.43)$ & $(1.52)$ & $(0.99)$ & $(2.11)^{* *}$ & $(2.00)^{*}$ & $(2.85)^{* * *}$ \\
\hline \multirow[t]{2}{*}{ TOT volatility } & & & -0.092 & & 0.015 & \\
\hline & & & $(2.49)^{* *}$ & & $(0.29)$ & \\
\hline \multirow[t]{2}{*}{ RER volatility } & & & & -4.187 & -4.229 & \\
\hline & & & & $(5.49)^{* * *}$ & $(4.50) * * *$ & \\
\hline \multirow[t]{2}{*}{ Mismatch } & & & & & & -2.928 \\
\hline & & & & & & $(3.65)^{* * *}$ \\
\hline \multirow[t]{2}{*}{ Constant } & -8.062 & -5.962 & -5.931 & 8.394 & 8.114 & -9.000 \\
\hline & $(2.12)^{* *}$ & $(1.28)$ & $(1.66)$ & $(1.83)^{*}$ & $(1.69)^{*}$ & $(2.39)^{* *}$ \\
\hline Observations & 56 & 49 & 54 & 41 & 40 & 45 \\
\hline
\end{tabular}


Table 6: Composition outstanding of international securities issued by non-US residents and held by US investors. (2001)

\begin{tabular}{|c|c|c|c|c|c|c|c|c|c|c|c|}
\hline & USD & EUR & JPY & GBP & OWN & Other & Total & $\begin{array}{c}\text { Share of } \\
\text { Total }\end{array}$ & $\begin{array}{c}\text { Share of } \\
\text { international } \\
\text { securities (a) }\end{array}$ & $\begin{array}{l}\text { Securities by } \\
\text { currency (b) }\end{array}$ & $\begin{array}{l}\text { Currency } \\
\text { share (c) }\end{array}$ \\
\hline Financial Centers & 137.4 & 5.1 & 32.5 & 16.1 & 0.1 & 0.3 & 191.6 & 29.57 & 19.45 & 511.8 & 79.00 \\
\hline Euroland & 81.8 & 87.9 & 1.9 & 1.0 & 0.0 & 0.3 & 172.8 & 26.68 & 6.74 & 97.3 & 15.02 \\
\hline Other Developed & 115.3 & 1.0 & 0.7 & 0.5 & 34.1 & 0.3 & 151.8 & 23.44 & 29.91 & 34.1 & 5.26 \\
\hline Offshore & 32.7 & 1.8 & 0.5 & 0.5 & 0.5 & 0.0 & 36.1 & 5.57 & 69.73 & 0.5 & 0.08 \\
\hline Developing & 80.0 & 0.9 & 0.2 & 0.1 & 2.6 & 0.1 & 84.0 & 12.96 & 17.09 & 2.6 & 0.41 \\
\hline Int. Organizations & 9.0 & 0.6 & 0.8 & 0.6 & 0.0 & 0.6 & 11.5 & 1.78 & 3.05 & 0.0 & 0.00 \\
\hline Other and Unallocated & & & & & & & & & & 1.5 & 0.23 \\
\hline TOTAL & 456.0 & 97.3 & 36.7 & 18.9 & 37.4 & 1.5 & 647.8 & 100 & 13.01 & 647.8 & 100 \\
\hline
\end{tabular}

(a) Share of international securities held by US investors over total international bonds issued in 2001 by non-US resident

(b) and (c) International securities (and their share) held by US investors in each of the currency groups (for instance, at the end of 2001 US investor held USD97.3 billion worth of international securities denominated in euro, this corresponds to 15 percent of the total international securities held by US investors)

The OWN currency column is set equal to zero for Euroland (everything is reported under the euro column) and in, the case of financial centers, for Japan, and United Kingdom. The value reported under OWN for financial centers corresponds to issues in Swiss francs.

Source: Authors calculations based on Tables 16 and 17 in Report on US holdings of foreign securities. Us Treasury, Available at http://www.treas.gov/tic/shc2001r.pdf 
Table 7: Original Sin and Credit Rating in Developing and Industrial Countries

\begin{tabular}{|c|c|c|c|c|}
\hline & (1) & (2) & (3) & (4) \\
\hline \multirow{3}{*}{ Original Sin } & RATING & RATING & RATING & RATING \\
\hline & -5.100 & -5.385 & -4.751 & -5.101 \\
\hline & $(3.38)^{* * *}$ & $(3.46)^{* * *}$ & $(3.32) * * *$ & $(3.53) * * *$ \\
\hline \multirow[t]{2}{*}{ DE_GDP*IND } & -1.553 & & -2.451 & \\
\hline & $(1.31)$ & & $(2.05) * *$ & \\
\hline \multirow[t]{2}{*}{ DE_GDP*DEV } & -3.557 & & -2.475 & \\
\hline & $(2.66)^{* *}$ & & $(1.84)^{*}$ & \\
\hline \multirow[t]{2}{*}{ DE_RE*IND } & & -0.860 & & -1.354 \\
\hline & & $(1.57)$ & & $(2.45)^{* *}$ \\
\hline \multirow[t]{2}{*}{ DE_RE*DEV } & & -1.113 & & -0.847 \\
\hline & & $(2.22)^{* *}$ & & $(1.79)^{*}$ \\
\hline \multirow[t]{2}{*}{ GDP per cap } & 2.663 & 2.575 & 1.936 & 1.729 \\
\hline & $(6.71)^{* * *}$ & $(5.12)^{* * *}$ & $(4.00)^{* * *}$ & $(3.01)^{* * *}$ \\
\hline \multirow{2}{*}{ Ex Debt/GDP } & 2.252 & 2.799 & 1.751 & 2.015 \\
\hline & $(1.50)$ & $(1.54)$ & $(1.22)$ & (1.17) \\
\hline \multirow[t]{2}{*}{ Developing } & & & -3.004 & -3.226 \\
\hline & & & $(2.38) * *$ & $(2.52)^{* *}$ \\
\hline \multirow[t]{2}{*}{ Constant } & -6.314 & -5.288 & 1.606 & 4.085 \\
\hline & (1.58) & $(1.06)$ & $(0.32)$ & $(0.69)$ \\
\hline Observations & 56 & 49 & 56 & 49 \\
\hline
\end{tabular}

Weighed Tobit Estimations Absolute value of $\mathrm{t}$ statistics in parentheses

* significant at $10 \%$; $*$ significant at $5 \%$; *** significant at $1 \%$ 
Table 8: Original Sin, Debt Intolerance and Exchange Rate Volatility

\begin{tabular}{|c|c|c|c|c|c|c|c|c|c|}
\hline & (1) & (2) & (3) & (4) & (5) & (6) & (7) & (8) & (9) \\
\hline & LYS & LYS & LYS & RESM2 & RESM2 & RESM2 & RVER & RVER & RVER \\
\hline \multirow{2}{*}{ Original Sin } & 1.737 & 1.886 & 1.738 & 0.271 & 0.247 & 0.271 & -0.843 & -0.136 & -0.809 \\
\hline & $(3.74)^{* * *}$ & $(3.89)^{* * *}$ & $(3.85)^{* * *}$ & $(4.09)^{* * *}$ & $(3.61)^{* * *}$ & $(4.11)^{* * *}$ & $(2.18)^{* *}$ & $(0.76)$ & $(2.02)^{* *}$ \\
\hline \multirow[t]{2}{*}{ GDP per cap } & 0.259 & 0.220 & 0.259 & -0.034 & -0.044 & -0.034 & 0.124 & 0.033 & -0.001 \\
\hline & (1.94)* & (1.69)* & $(2.39)^{* *}$ & $(1.12)$ & $(1.72)^{*}$ & $(1.57)$ & (1.78)* & $(1.66)$ & $(0.03)$ \\
\hline \multirow[t]{2}{*}{ Openness } & 0.208 & 0.391 & 0.208 & 0.007 & 0.079 & 0.007 & 0.990 & -0.057 & 1.052 \\
\hline & $(0.84)$ & $(0.86)$ & $(0.85)$ & $(0.22)$ & $(1.20)$ & $(0.22)$ & $(4.37)^{* * *}$ & $(0.68)$ & $(3.70)^{* * *}$ \\
\hline Ex debt/GDP & $\begin{array}{c}-0.004 \\
(0.01)\end{array}$ & $\begin{array}{l}0.069 \\
(0.20)\end{array}$ & & $\begin{array}{l}0.001 \\
(0.00)\end{array}$ & $\begin{array}{l}-0.050 \\
(0.62)\end{array}$ & & $\begin{array}{c}-1.603 \\
(2.85)^{* * *}\end{array}$ & $\begin{array}{l}0.072 \\
(0.80)\end{array}$ & \\
\hline DI1 & $\begin{array}{l}2.435 \\
(0.19)\end{array}$ & & $\begin{array}{l}2.377 \\
(0.43)\end{array}$ & $\begin{array}{l}-1.012 \\
(0.43)\end{array}$ & & $\begin{array}{l}-1.006 \\
(0.83)\end{array}$ & $\begin{array}{c}17.456 \\
(2.52)^{* *}\end{array}$ & & $\begin{array}{l}2.368 \\
(0.83)\end{array}$ \\
\hline DI2 & & $\begin{array}{l}-1.849 \\
(0.74)\end{array}$ & & & $\begin{array}{c}-0.766 \\
(1.70)^{*}\end{array}$ & & & $\begin{array}{l}0.299 \\
(1.26)\end{array}$ & \\
\hline Constant & $\begin{array}{l}-2.033 \\
(1.48)\end{array}$ & $\begin{array}{l}-1.817 \\
(1.26)\end{array}$ & $\begin{array}{l}-2.030 \\
(1.66)\end{array}$ & $\begin{array}{l}0.338 \\
(1.12)\end{array}$ & $\begin{array}{l}0.415 \\
(1.47)\end{array}$ & $\begin{array}{l}0.337 \\
(1.41)\end{array}$ & $\begin{array}{l}-0.825 \\
(1.07)\end{array}$ & $\begin{array}{l}0.002 \\
(0.01)\end{array}$ & $\begin{array}{l}0.151 \\
(0.24)\end{array}$ \\
\hline Observations & 59 & 51 & 59 & 53 & 46 & 53 & 52 & 45 & 52 \\
\hline R-squared & & & & 0.34 & 0.40 & 0.34 & 0.73 & 0.25 & 0.69 \\
\hline
\end{tabular}

Equations 1, 2, and 3are estimated with weighed Tobit model. All the other equations are estimated with weighed OLS with robust standard errors. 
Table 9: Original Sin, Debt Intolerance, and GDP and Capital Flow Volatility

\begin{tabular}{|c|c|c|c|c|c|c|c|c|c|c|c|}
\hline & (1) & (2) & (3) & (4) & (5) & (6) & (7) & (8) & (9) & (10) & (11) \\
\hline & Growth & Flows & Growth & Growth & Flows & Flows & Flows & Flows & Flows & Flows & Flows \\
\hline \multirow{2}{*}{ Original Sin } & 0.013 & 0.015 & 0.013 & 0.015 & 5.271 & 9.163 & 6.693 & 8.959 & 3.155 & 5.630 & 5.547 \\
\hline & $(2.45)^{* *}$ & $(2.84)^{* * * *}$ & $(2.46)^{* *}$ & $(2.77)^{* * *}$ & $(2.77)^{* *}$ & $(4.48)^{* * *}$ & $(3.15)^{* * *}$ & $(4.19)^{* * *}$ & $(1.82)^{*}$ & $(2.35)^{* *}$ & $(2.15)^{* *}$ \\
\hline \multirow[t]{2}{*}{ GDP per cap } & -0.007 & -0.008 & -0.007 & -0.009 & -1.234 & -2.173 & -3.041 & -2.340 & 2.012 & 1.469 & 1.240 \\
\hline & $(2.04)^{* *}$ & $(2.65)^{* *}$ & $(2.98)^{* * *}$ & $(2.85)^{* * *}$ & (1.13) & $(2.43)^{* *}$ & $(2.58)^{* *}$ & $(2.48)^{* *}$ & (1.16) & $(0.99)$ & $(0.87)$ \\
\hline \multirow[t]{2}{*}{ Openness } & 0.002 & -0.005 & 0.002 & -0.006 & -1.606 & -1.918 & -6.413 & -3.357 & 3.139 & 3.948 & 2.243 \\
\hline & $(0.41)$ & $(0.50)$ & $(0.50)$ & $(0.65)$ & $(0.35)$ & $(0.44)$ & (1.67) & $(0.91)$ & (1.10) & $(1.22)$ & $(0.79)$ \\
\hline \multirow[t]{2}{*}{ TOT volatility } & 0.000 & 0.000 & 0.000 & 0.000 & 0.145 & -0.159 & 0.217 & -0.137 & 0.100 & -0.224 & -0.197 \\
\hline & $(0.23)$ & $(0.13)$ & $(0.37)$ & $(0.24)$ & $(0.59)$ & (1.65) & $(1.03)$ & $(1.55)$ & $(0.49)$ & $(1.86)^{*}$ & (1.59) \\
\hline \multirow[t]{2}{*}{ Ex debt/GDP } & -0.008 & -0.005 & & & -20.531 & -2.797 & & & -0.616 & -3.093 & \\
\hline & $(0.42)$ & $(0.65)$ & & & $(1.83)^{*}$ & (1.14) & & & $(0.23)$ & (1.10) & \\
\hline DI1 & -0.026 & & -0.109 & & 355.751 & & 57.418 & & & & \\
\hline DI2 & $(0.0)$ & $\begin{array}{l}-0.075 \\
(1.19)\end{array}$ & $(0.01)$ & -0.078 & & $\begin{array}{c}52.839 \\
(4.85) * * *\end{array}$ & & $\begin{array}{c}52.850 \\
(4.87)^{* * *}\end{array}$ & & & \\
\hline Rating & & & & & & & & & $\begin{array}{c}-1.494 \\
(2.54)^{* *}\end{array}$ & $\begin{array}{c}-1.337 \\
(2.51)^{* *}\end{array}$ & $\begin{array}{l}-1.316 \\
(2.44)^{* *}\end{array}$ \\
\hline Pub Debt/GDP & & & & & & & & & & $\begin{array}{l}1.686 \\
(0.60)\end{array}$ & $\begin{array}{l}1.839 \\
(0.66)\end{array}$ \\
\hline Constant & $\begin{array}{c}0.078 \\
(2.35)^{* *}\end{array}$ & $\begin{array}{c}0.093 \\
(2.80)^{* * *}\end{array}$ & $\begin{array}{c}0.082 \\
(3.01)^{* * *}\end{array}$ & $\begin{array}{c}0.097 \\
(2.94)^{* * *}\end{array}$ & $\begin{array}{l}13.241 \\
(1.03)\end{array}$ & $\begin{array}{l}22.635 \\
(2.36)^{* *}\end{array}$ & $\begin{array}{c}31.258 \\
(2.37)^{* *}\end{array}$ & $\begin{array}{c}23.906 \\
(2.39)^{* *}\end{array}$ & $\begin{array}{l}5.858 \\
(0.58)\end{array}$ & $\begin{array}{l}9.169 \\
(0.91)\end{array}$ & $\begin{array}{l}10.562 \\
(1.08)\end{array}$ \\
\hline Observations & 62 & 54 & 62 & 54 & 29 & 26 & 29 & 26 & 29 & 26 & 26 \\
\hline R-squared & 0.38 & 0.35 & 0.38 & 0.35 & 0.64 & 0.75 & 0.60 & 0.74 & 0.68 & 0.73 & 0.73 \\
\hline $\begin{array}{l}\text { Sum of } \\
\text { coefficients }\end{array}$ & & & & & & & & & $\begin{array}{c}\text { DEBT+ } \\
\text { RATING }\end{array}$ & $\begin{array}{c}\text { DEBT+ } \\
\text { RATING } \\
\text { +DE GDP }\end{array}$ & $\begin{array}{l}\text { RATING } \\
\text { +DE_GDP }\end{array}$ \\
\hline $\begin{array}{l}\text { evaluated at } \\
\text { the mean }\end{array}$ & & & & & & & & & -20.58 & -18.84 & -17.16 \\
\hline Test & & & & & & & & & $\begin{array}{c}F(1,22)=6.1 \\
P=0.022\end{array}$ & $\begin{array}{c}\mathrm{F}(1,18)=6.0 \\
\mathrm{P}=0.025\end{array}$ & $\begin{array}{c}\mathrm{F}(1.19)=6.5 \\
\mathrm{P}=0.020\end{array}$ \\
\hline
\end{tabular}

Robust $t$ statistics in parentheses
$*$ significant at $10 \% ; *$ significant at $5 \% ; * * *$ significant at $1 \%$ 
Table 10: The Causes of Original Sin

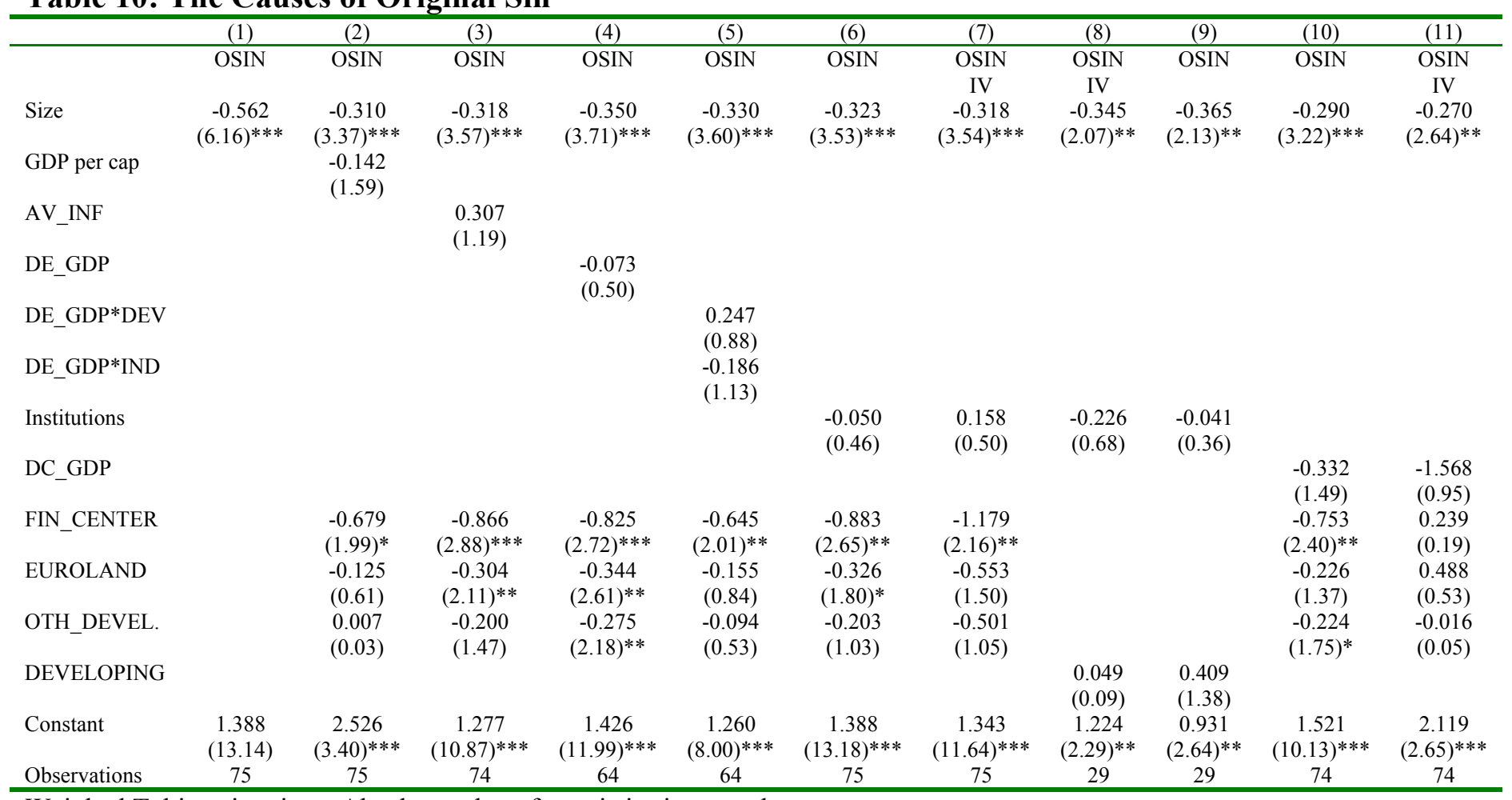

Weighed Tobit estimations. Absolute value of $t$ statistics in parentheses

$*$ significant at $10 \%$; * significant at $5 \%$; *** significant at $1 \%$ 
Table 11: The Causes of Original Sin: Encompassing Tests

\begin{tabular}{lcccc}
\hline & $(1)$ & $(2)$ & $(3)$ & $(4)$ \\
\hline & OSIN & OSIN & OSIN & OSIN \\
Size & -0.302 & -0.325 & -0.326 & -0.333 \\
& $(3.32)^{* * *}$ & $(3.48)^{* * *}$ & $(3.50)^{* * *}$ & $(3.52)^{* * *}$ \\
GDP per cap & -0.262 & -0.127 & & \\
& $(2.08)^{* *}$ & $(1.31)$ & & \\
AV_INF & 0.288 & 0.150 & 0.070 & -0.060 \\
& $(0.89)$ & $(0.49)$ & $(0.29)$ & $(0.14)$ \\
DE_GDP & -0.003 & -0.102 & 0.044 & -0.059 \\
& $(0.02)$ & $(0.60)$ & $(0.26)$ & $(0.28)$ \\
Institutions & 0.305 & & 0.091 & -0.120 \\
& $(1.88)^{*}$ & & $(0.70)$ & $(0.33)$ \\
DC_GDP & -0.313 & -0.173 & -0.403 & -0.319 \\
& $(1.05)$ & $(0.59)$ & $(1.38)$ & $(1.19)$ \\
FIN_CENTER & -0.492 & -0.453 & -0.680 & -0.479 \\
& $(1.45)$ & $(1.31)$ & $(2.06)^{* *}$ & $(0.91)$ \\
EUROLAND & 0.032 & 0.010 & -0.220 & -0.074 \\
& $(0.15)$ & $(0.04)$ & $(1.18)$ & $(0.22)$ \\
OTH_DEVEL. & -0.053 & 0.030 & -0.299 & -0.072 \\
& $(0.24)$ & $(0.14)$ & $(1.55)$ & $(0.17)$ \\
DEVELOPING & & & & \\
& & & & \\
Constant & 3.506 & 2.505 & 1.516 & 1.618 \\
& $(3.54)^{* * *}$ & $(3.22)^{* * *}$ & $(7.66)^{* * *}$ & $(4.89)^{* * *}$ \\
Observations & 63 & 63 & 63 & 63 \\
\hline
\end{tabular}

Weighed Tobit estimations. Absolute value of $\mathrm{t}$ statistics in parentheses

$*$ significant at $10 \% ; * *$ significant at $5 \%$; *** significant at $1 \%$ 
Table 12: The Causes of Original Sin omitting Country-Group Fixed Effects

\begin{tabular}{|c|c|c|c|c|c|c|c|c|c|c|}
\hline & $(1)$ & $(2)$ & (3) & $(4)$ & $(5)$ & $(6)$ & $(7)$ & $(8)$ & $(9)$ & $(10)$ \\
\hline & OSIN & OSIN & OSIN & OSIN & OSIN & $\begin{array}{c}\text { OSIN } \\
\text { (IV) }\end{array}$ & $\begin{array}{c}\text { OSIN } \\
\text { (IV) }\end{array}$ & OSIN & OSIN & $\begin{array}{c}\text { OSIN } \\
\text { (IV) }\end{array}$ \\
\hline SIZE & $\begin{array}{c}-0.415 \\
(4.51)^{* * *}\end{array}$ & $\begin{array}{c}-0.495 \\
(5.71)^{* * *}\end{array}$ & $\begin{array}{c}-0.555 \\
(5.92)^{* * *}\end{array}$ & $\begin{array}{c}-0.414 \\
(4.54)^{* * *}\end{array}$ & $\begin{array}{c}-0.480 \\
(5.32)^{* * *}\end{array}$ & $\begin{array}{c}-0.487 \\
(4.58)^{* * *}\end{array}$ & $\begin{array}{c}-0.358 \\
(2.17)^{* *}\end{array}$ & $\begin{array}{c}-0.435 \\
(2.97)^{* * *}\end{array}$ & $\begin{array}{c}-0.399 \\
(4.47)^{* * *}\end{array}$ & $\begin{array}{l}-0.84 \\
(0.38)\end{array}$ \\
\hline GDP per cap & $\begin{array}{c}-0.170 \\
(3.00)^{* * *}\end{array}$ & & & & & & & & & \\
\hline AV_INF & & $\begin{array}{c}0.610 \\
(2.20)^{* *}\end{array}$ & & & & & & & & \\
\hline DE_GDP & & & $\begin{array}{l}0.050 \\
(0.31)\end{array}$ & & & & & & & \\
\hline DE_GDP*DEV & & & & $\begin{array}{c}0.421 \\
(2.04)^{* *}\end{array}$ & & & & & & \\
\hline DE_GDP*IND & & & & $\begin{array}{l}-0.210 \\
(1.24)\end{array}$ & & & & & & \\
\hline INSTITUTIONS & & & & & $\begin{array}{c}-0.182 \\
(2.33)^{* *}\end{array}$ & $\begin{array}{l}-0.196 \\
(1.19)\end{array}$ & $\begin{array}{c}-0.309 \\
(1.92)^{*}\end{array}$ & $\begin{array}{c}-0.202 \\
(1.96)^{* *}\end{array}$ & & \\
\hline DC_GDP & & & & & & & & & $\begin{array}{c}-0.554 \\
(2.99)^{* * *}\end{array}$ & $\begin{array}{l}-3.22 \\
(1.52)\end{array}$ \\
\hline Constant & $\begin{array}{c}2.835 \\
(5.47)^{* * *}\end{array}$ & $\begin{array}{c}1.226 \\
(11.08)^{* * *}\end{array}$ & $\begin{array}{c}1.374 \\
(11.66)^{* * *}\end{array}$ & $\begin{array}{c}1.224 \\
(11.01)^{* * *}\end{array}$ & $\begin{array}{c}1.486 \\
(12.33)^{* * *}\end{array}$ & $\begin{array}{c}1.483 \\
(10.62)^{* * *}\end{array}$ & $\begin{array}{c}1.382 \\
(7.66)^{* * *}\end{array}$ & $\begin{array}{c}1.429 \\
(7.82)^{* * *}\end{array}$ & $\begin{array}{c}1.636 \\
(11.32)^{* * *}\end{array}$ & $\begin{array}{c}3.046 \\
(2.74)^{* * *}\end{array}$ \\
\hline Observations & 75 & 74 & 64 & 64 & 75 & 75 & 29 & 29 & 74 & 74 \\
\hline
\end{tabular}

Weighed Tobit estimations. Absolute value of t statistics in parentheses

* significant at $10 \% ; * *$ significant at $5 \%$; ** significant at $1 \%$ 
Table 13: The Causes of Original Sin:

Encompassing Tests Omitting Fixed Effects

\begin{tabular}{lccc}
\hline & $(1)$ & $(2)$ & $(3)$ \\
\hline \multirow{2}{*}{ SIZE } & OSIN & OSIN & OSIN \\
& & $($ IV $)$ & $($ IV $)$ \\
GDP per cap & -0.352 & -0.366 & -0.700 \\
& $(3.88)^{* * *}$ & $(3.43)^{* * *}$ & $(2.10)^{* *}$ \\
AV_INF & -0.248 & -0.156 & -0.269 \\
& $(2.30)^{* *}$ & $(0.52)$ & $(0.71)$ \\
DE_GDP & 0.274 & 0.164 & 0.775 \\
& $(0.88)$ & $(0.32)$ & $(0.84)$ \\
DC_GDP & -0.002 & -0.050 & -0.893 \\
& $(0.01)$ & $(0.26)$ & $(1.09)$ \\
INSTITUTIONS & -0.291 & -0.286 & 2.897 \\
& $(1.25)$ & $(1.08)$ & $(0.91)$ \\
Constant & 0.255 & 0.092 & -0.546 \\
& $(1.61)$ & $(0.15)$ & $(0.83)$ \\
Observations & 3.437 & 2.785 & 2.546 \\
& $(4.03)^{* * *}$ & $(1.31)$ & $(1.22)$ \\
Weighed Tobit estimations. Absolute value of t statistics in parentheses
\end{tabular}

Weighed Tobit estimations. Absolute value of $\mathrm{t}$ statistics in parentheses

$*$ significant at $10 \% ; * *$ significant at $5 \% ; * * *$ significant at $1 \%$ 
Figure 1: Domestic versus International Original Sin (2001)

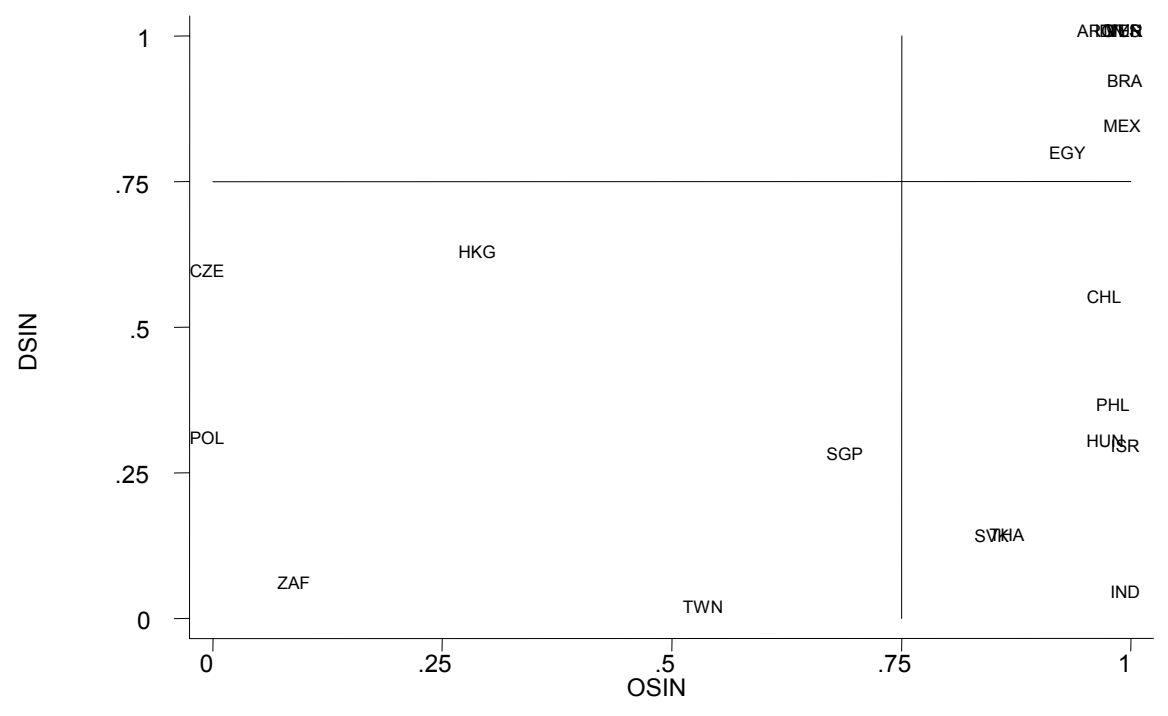

